\title{
Subfossil and periphytic diatoms from the upper Paraná river, Brazil: last $\sim 1000$ years of a transition period ${ }^{1}$
}

\author{
๑Daiane Trevisan Ruwer ${ }^{2,3}$ and Liliana Rodrigues ${ }^{2,3}$
}

Received: 4.12.2017; accepted: 6.06.2018

\begin{abstract}
Subfossil and periphytic diatoms from the upper Paraná river, Brazil: last $\sim 1000$ years of a transition period). Considering the lack of knowledge regarding the paleolimnology and the diatom flora from the sediment in Brazilian aquatic environments, this study aimed to provide information about diatom biodiversity and autoecology in an environment located in the upper Paraná river floodplain. Sediment and periphytic samples were collected from a swamp located in an island of the upper Paraná river floodplain. Sediment samples were obtained by collecting a core of $\sim 2 \mathrm{~m}$ with a calibrated date of 726 to $903 \mathrm{cal} \mathrm{yr} \mathrm{BP}$ near the base. The core was sliced into layers of $2.5 \mathrm{~cm}$, totaling 41 samples. Periphytic diatom samples were obtained by scraping macrophytes' petioles, totaling two samples. The community was represented by 31 species belonging to 15 genera. All of the taxa were found in the sediment record, and 15 were present in the periphyton. The three new records (Eunotia longicamelus, Planothidium bagualensis and Luticola hustedtii) reinforce the importance of paleolimnological and periphytic studies to increase information about the aquatic biodiversity.
\end{abstract}

Keywords: bioindicators, floodplain, freshwater, paleolimnology

RESUMO - (Diatomáceas subfósseis e perifíticas do alto rio Paraná, Brasil: últimos $\sim 1000$ anos de um período de transição). Considerando a falta de conhecimento paleolimnológico e da flora de diatomáceas do sedimento nos ambientes aquáticos brasileiros, este estudo teve como objetivo fornecer informações sobre biodiversidade e autoecologia de diatomáceas de um ambiente localizado na planície de inundação do alto rio Paraná. Amostras de sedimento e perifíton foram coletadas em um pântano localizado em uma ilha fluvial na planície de inundação do alto rio Paraná. As amostras de sedimento foram obtidas através da coleta de um testemunho de $\sim 2 \mathrm{~m}$, com uma data calibrada perto da base de 726 a 903 cal anos PB. O testemunho foi dividido em fatias de $2,5 \mathrm{~cm}$, totalizando 41 amostras. As amostras perifíticas foram obtidas através da raspagem de pecíolos de macrófitas, totalizando duas amostras. A comunidade foi representada por 31 espécies pertencentes a 15 gêneros. Todos os táxons foram encontrados no registro de sedimentos, e 15 estavam presentes no perifíton. Os três novos registros para a região (Eunotia longicamelus, Planothidium bagualensis e Luticola hustedtii) mostram a importância dos estudos paleolimnológicos e da comunidade perifítica para aumentar a informação sobre a biodiversidade aquática.

Palavras-chave: água doce, bioindicadores, paleolimnologia, planície de inundação,

\section{Introduction}

Taxonomic diversity is one of the most important characteristics of biological communities that reflect evolutionary and ecological processes (Komulaynen 2009). Species richness is a basic and fundamental measurement of community and regional diversity (Magurran 1988). Several factors affect small-scale species richness. According to reviews, alteration, and loss of habitat, hydrological modification, pollution, and invasion have been identified as the main drivers of species reduction (Stendera et al. 2012).
Palaeolimnological studies are a tool to evaluate changes in the environments over time and access the ancient biodiversity. Past communities are very often the only available tool to provide information on natural biodiversity before human impacts (Smucker \& Vis 2010). Therefore, the data from these studies become an important appliance for conservation actions in freshwater environments (Smol 1992, Saulnier-Talbot 2016).

Diatoms are widely used on paleolimnological studies (Gabito et al. 2013), these organisms precipitate and are incorporated in the sediment

1. Parte da Dissertação de Mestrado do primeiro Autor

2. Universidade Estadual de Maringá, Departamento de Biologia, Núcleo de Pesquisas em Limnologia, Ictiologia e Aquicultura, Av. Colombo, 5790, Zona 7, 87020-900 Maringá, PR, Brasil

3. Corresponding author: dai.ruwer@gmail.com 
due to their biogenic structures constituted of silica (Sierra-Arango et al. 2014). Diatoms respond sensibly (directly and indirectly) to a wide range of aquatic environmental stimuli, including physical and chemical changes (Douglas \& Smol 1999, Stevenson $\&$ Pan 1999). The information provided by the diatoms enables us to understand the degree of changes that have was found in the habitat, for example, variation in water level and influence of erosion, or even introduction of species and extinctions (Smol 1992, Battarbee 1999).

Regardless of the importance of these studies on biodiversity changes, these applications have been scarce in tropical environments (Rühland et al. 2015). Palaeolimnological studies addressing taxonomy and richness of diatoms are even rarer, and for Brazil there are only a few studies (Fontana \& Bicudo 2009, 2012, Almeida \& Bicudo 2014, Silva \& Bicudo 2014, Wengrat et al. 2015, Almeida et al. 2015, Faustino et al. 2016), which concentrate focus on surface sediments of reservoirs from São Paulo State. However, there is still rare taxonomic work addressing Brazilian subfossil diatoms with sediments of more than 100 years and also from the floodplain.

Therefore, considering the lack of palaeolimnological studies concerning diatom flora from the sediment of the Brazilian aquatic environments and given, the current transformations in the global and regional environments, this study aimed to provide information about the diatom biodiversity and autoecology from a tropical floodplain.

\section{Materials and methods}

The study area is located on a swamp on an island in the Paraná River, in the upper Paraná river floodplain, in the reach between the reservoirs of Porto Primavera and Itaipu Lake. The Mutum Island presented $15 \mathrm{~km}$ long, with variable width (high and low waters) between 0.5 and $1.20 \mathrm{~km}$ and height of 5.0 $\mathrm{m}$ above the average level of the River. The sampling site is located in the central region of the swamp $\left(22^{\circ} 45^{\prime} 31.98^{\prime \prime}\right.$ S and $\left.53^{\circ} 17^{\prime} 52.60^{\prime \prime} \mathrm{W}\right)$ (figure 1$)$ with depth less than one meter.

A sediment core with a length of two meters was removed with a vibrocore. The sediment was analyzed according to granulometry, structure, composition, and coloration. With this analysis, it was possible to identify 5 geomorphological zones matching the geomorphological process of the fluvial islands approached in the studies of Fernandez et al.

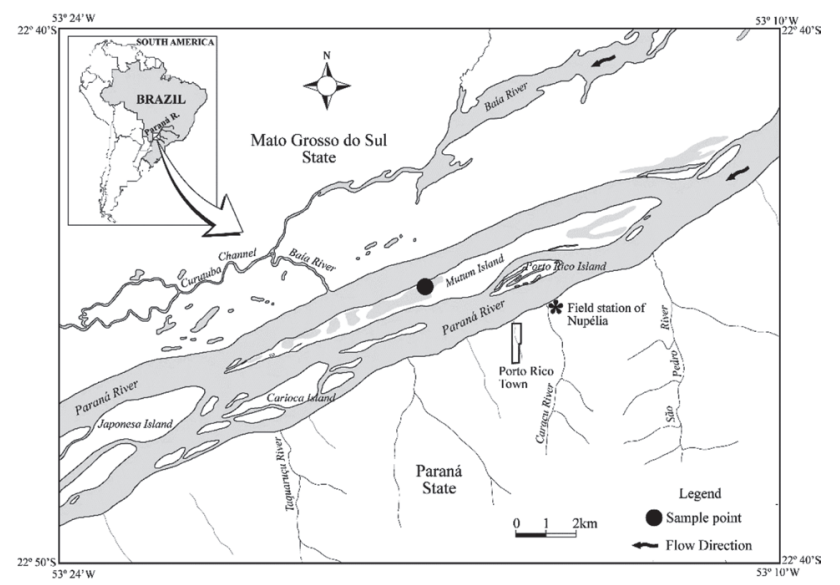

Figure 1. Sampling point in the Mutum, island upper Paraná river floodplain, Brazil.

(1993) and Steauvx (1994). According to Fernandez et al. (1993) and Steauvx (1994), the fluvial islands in the upper Paraná river floodplain are formed by coalescence processes of bars to the islands. This process begins with the formation of the original island through a deposition of sediment. After its permanent establishment, there is the formation of a lateral bar of sediment on the side of the original island. The original island and the sidebar will be separated by a channel, which due to the sediment flow will become a connected lake or backwater, consequently, in a lake, transition period and, at the end of the process will be a swamp (see figure 2 in Ruwer \& Rodrigues 2018).

With small amounts of sediment from the depths $0.78 \mathrm{~m}, 1.40 \mathrm{~m}$ and $1.90 \mathrm{~m}$, data were analyzed with radiocarbon analysis. The analyses were performed by the Center for Applied Isotope Studies - CAIS (University of Georgia, USA) and the Nuclear Energy Center in Agriculture - CENA (São Paulo University). Radiocarbon ages were calibrated (cal yr BP and cal yr AD) by CALIB7.0.4 using the SHCal13 calibration curve for the Southern Hemisphere (Stuiver and Reimer 1993, Hogg et al. 2013). The absolute dating with the isotope of ${ }^{14} \mathrm{C}$ in the samples of depths: $78 \mathrm{~cm}$, $140 \mathrm{~cm}$, and $190 \mathrm{~cm}$, indicated modern age, $760 \pm 65 \mathrm{yr}$ $\mathrm{BP}(569$ to $721 \mathrm{cal} \mathrm{yr} \mathrm{BP})$ and $920 \pm 60{ }^{14} \mathrm{C}$ yr BP (726 to 903 cal yr BP), respectively. In addition, the record was separated into $2.5 \mathrm{~cm}$ slices with $5 \mathrm{~cm}$ of intervals and disregarding the first $5 \mathrm{~cm}$ (from the top of the core). From each $2.5 \mathrm{~cm}$ slice, $0.01 \mathrm{~g}$ of sediment was removed for the preparation of permanent slides for subsequent quantitative and qualitative analysis under a microscope. The methodology for the preparation of slides was based on Battarbee et al. (2001). Diatom analysis was carried out on 32 out of 41 samples. 

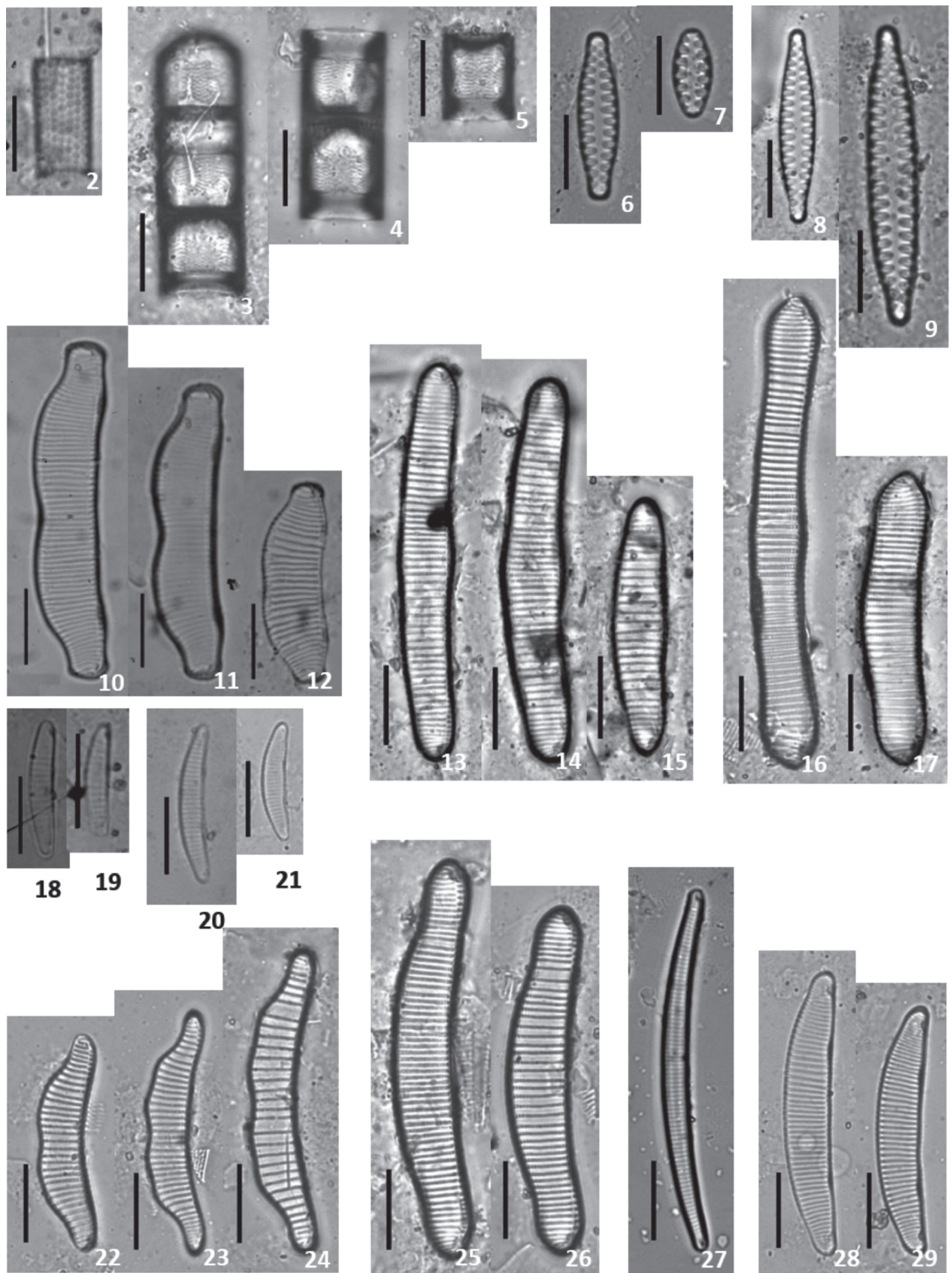

Figures 2-29. Diatom species from Mutum Island in the upper Paraná river floodplain, Brazil (LM). 2. Aulacoseira granulata. 3-5. Aulacoseira italica. 6-7. Staurosirella crassa mf. I. 8-9. Staurosirella crassa. 10-12. Eunotia bidens. 13-15. Eunotia cf. deformis. 16-17. Eunotia formica. 18-19. Eunotia cf. intermedia. 20-21. Eunotia subarcuatoides. 22-24. Eunotia longicamelus. 25-26. Eunotia major. 27. Eunotia naegelli. 28-29. Eunotia pseudosudetica. (Scale bar: $10 \mu \mathrm{m}$ ). 
Nine samples were not found a sufficient number of diatoms for analysis (78307UPCB to 78310UPCB, 78318 UPCB to 78322 UPCB).

Given the high dominance of diatoms in periphytic samples (Biolo \& Rodrigues 2013, Bichoff et al. 2016), the periphytic community was sampled in order to identify diatom communities from the current environment. The sampling of the periphytic diatom community was made in April 2016 after a period of flooding. The following abiotic parameters were measured in situ with a multi-parameter probe: dissolved oxygen (percentage saturation and $\mathrm{g} / \mathrm{L}$ ), $\mathrm{pH}$, water temperature $\left({ }^{\circ} \mathrm{C}\right)$, electric conductivity $(\mu \mathrm{S} / \mathrm{cm})$, turbidity (NTU), total solids $(\mathrm{g} / \mathrm{L})$ and salinity (ppt) (Mackareth et al. 1978, Wetzel \& Likens 1981).

Periphytic diatom community was obtained by scraping mature petioles of an aquatic macrophyte. Two petioles were collected in the sampling site, placed in $150 \mathrm{ml}$ Wheaton bottles and kept cool until further removal of the periphytic biofilm, which was performed using a stainless-steel blade wrapped in aluminum foil and jets of distilled water. After removal, periphyton was fixed and preserved in Transeau solution (Bicudo \& Menezes 2017). The periphytic material was oxidized and cleaned using the Simonsen (1974) method, modified by Moreira-Filho \& Valente-Moreira (1981) and prepared on permanent slides with Naphrax resin. We analyzed the samples of non-oxidized periphyton under the optical microscope, to observe the forms of arrangement and fixation of the species.

The quantitative analysis was performed according to the method of Battarbee et al. (1986) with the count of at least 500 valves in an optical microscope. The slides were analyzed qualitatively under an optical microscope (under $1000 \times$ magnification) and scanning electron microscopy (Ferrario et al. 1995). The samples were deposited in the herbarium of Botanic Department of Universidade Federal do Paraná (78280UPCB to 78322UPCB). We recorded 329 taxa in the study, and we presented here only the taxa that occurred with a relative abundance of $\geq 20 \%$, which contributed $74 \%$ of the relative abundance of all samples. Has been adopted the Round et al. (1990) classification system.

\section{Results and Discussion}

The swamp in the current period was characterized by relatively high temperature, slightly acidic $\mathrm{pH}$, low conductivity, low dissolved oxygen concentration and high turbidity (table 1).

In the total 329 taxa found in the 34 samples, 31 species had a high abundance. The community was represented by 15 genera, among which the most representative were Eunotia Ehrenberg (10), Gomphonema Ehrenberg (three) and Luticola D.G. Mann (three).

\section{Bacillariophyta \\ Coscinodiscophyceae \\ Aulacoseirales \\ Aulacoseiraceae}

Aulacoseira granulata (Ehrenberg) Simonsen, Bacillaria, 2: 58, 1979 E Gaillonella granulata Ehrenberg in Abhandlungen der Königlichen Akademie der Wissenschaften zu Berlin 1841: 127, 1843. Melosira granulata Ralfs in Pritchard, Hist. Infus. 4: 820, 1861.

Figure 2

Diameter: $8-17 \mu \mathrm{m}$; height: 14-30 $\mu \mathrm{m}$; striae: 9-14/10 $\mu \mathrm{m}$.

Material examined: Brazil. Paraná: Porto Rico, Ilha Mutum, sediment, 27/II/2012, Ruwer et al. (78282UPCB - $78285 \mathrm{UPCB}, 78287 \mathrm{UPCB}$ - $78296 \mathrm{UPCB}, 78300 \mathrm{UPCB}, 78305 \mathrm{UPCB}$, 78312UPCB, 78315UPCB).

Ecological information: this species generally has a planktonic habitat, but can be also found in the periphytic community. Dominant in shallow lakes, it occurs in mesotrophic to eutrophic waters but is commonly found in eutrophic waters. This species occurs in alkaline waters and tolerate temperatures

Table 1. Abiotic variables of the swamp located in the Mutum island in the upper Paraná river floodplain, Brazil, in April 2016 (OD - dissolved oxygen; TDS - total dissolved solids).

\begin{tabular}{lc}
\hline Variables & Values \\
\hline Temperature $\left({ }^{\circ} \mathrm{C}\right)$ & 27.92 \\
$\mathrm{pH}$ & 6.19 \\
Conductivity $(\mathrm{mS} / \mathrm{cm})$ & 0.112 \\
Turbidity $(\mathrm{NTU})$ & 10.8 \\
DO $(\mathrm{g} / \mathrm{L})$ & 0.0023 \\
DO $(\%)$ & 30 \\
TDS $(\mathrm{g} / \mathrm{L})$ & 0.073 \\
Salinity $(\mathrm{ppt})$ & 0.1 \\
\hline
\end{tabular}


of 15 to over $30^{\circ} \mathrm{C}$ (Van Dam et al. 1994, Moro \& Fürstenberger 1997, Taylor et al. 2007, Zalat \& Vildary 2007, Kiss et al. 2012, Estepp \& Reavie 2015, Bicudo et al. 2016, Faustino et al. 2016). According to some works, this species is associated with water column mixing, high flood conditions and depth variations, and physical alterations as erosion events, turbulence, and deforestation (Zalat \& Vildary 2007, Dong et al. 2008, Costa-Böddeker et al. 2012, Fontana et al. 2014). This species was found in $52 \%$ of the samples, presenting greater abundance in the transition and swamp periods, with the highest abundance between these two periods.

Aulacoseira italica (Ehrenberg) Simonsen, Bacillaria, 2: 60, 1979 三 Gaillonella italica Ehrenberg in Bericht über die zur Bekanntmachung geeigneten Verhandlungen der Königlich Preussischen Akademie der Wissenschaften zu Berlin 1836: 53. 1836. Melosira italica (Ehrenberg) Kützing in Bacillarien 55, 1844.

Figures 3-5, 64

Diameter: 9-20 $\mu \mathrm{m}$; height: 12-24 $\mu \mathrm{m}$; inconspicuous striae.

Material examined: Brazil. Paraná: Porto Rico, Ilha Mutum, sediment, 27-II-2012, Ruwer et al. (78282UPCB - 78288UPCB, $78290 \mathrm{UPCB}$ - $78311 \mathrm{UPCB}, 78313 \mathrm{UPCB}$ - $78315 \mathrm{UPCB}$, 78317UPCB).

Ecological information: species generally of planktonic habitat, but also found in the periphytic community. Dominant in shallow lakes, occurring in oligotrophic to eutrophic waters, tolerate temperatures of 0 to $30{ }^{\circ} \mathrm{C}$ (Van Dam et al. 1994, Moro \& Fürstenberger 1997, Estepp \& Reavie 2015). Species of Aulacoseira genus has heavy silicified cells with a high sinking rate (characteristic clearly observed in the Aulacoseira italica of this study), therefore, this species requires turbulence to maintain its presence in the water column (Bradbury 1975). This species was found in $85 \%$ of the samples. With greater abundance in the transition and swamp periods, with the highest abundance between the transition and lake periods.

\footnotetext{
Bacillariophyceae

Fragilariales

Fragilariaceae
}

Staurosirella crassa (Metzeltin \& Lange-Bertalot) Ribeiro \& Torgan in Ribeiro et al., Revista Brasileira de Paleontologia, 13(1): 24, $2010 \equiv$ Fragilaria crassa Metzeltin \& Lange-Bertalot in Iconographia Diatomologica, 5: 89, fig. 1: 20-23, fig. 2:1, 1998. Figures 6-7, 65

Length: $36-87.8 \mu \mathrm{m}$; breadth: 10-10.1 $\mu \mathrm{m}$; striae: 5-6/10 $\mu \mathrm{m}$.

Material examined: Brazil. Paraná: Porto Rico, Ilha Mutum, sediment, 27-II-2012, Ruwer et al. (78282UPCB - 78296UPCB, $78299 \mathrm{UPCB}$ - $78302 \mathrm{UPCB}, 78304 \mathrm{UPCB}, 78306 \mathrm{UPCB}$ 78317UPCB).

Ecological information: episamic species (Ribeiro et al. 2008), was found in $82 \%$ of the samples with higher values of abundance during the swamp and connected lake periods. In Brazil, it was recorded by Dunck et al. (2012) in a lentic, oligotrophic to mesotrophic environments and by Ribeiro et al. (2010) for sediment samples from a coastal zone.

Staurosirella crassa morpho. I (Metzeltin \& Lange-Bertalot) Ribeiro \& Torgan in Ribeiro et al., Revista Brasileira de Paleontologia 13(1):24, $2010 \equiv$ Fragilaria crassa Metzeltin \& Lange-Bertalot in Iconographia Diatomologica, 5: 89, fig. 1:20-23, fig. 2:1, 1998 .

Figures 8-9

Length: 14.1-58 $\mu \mathrm{m}$; breadth: 4.8-9 $\mu \mathrm{m}$; striae: 5-8/10 $\mu \mathrm{m}$.

Material examined: Brazil. Paraná: Porto Rico, Ilha Mutum, sediment, 27/II/2012, Ruwer et al. (78282UPCB - 78296UPCB, 78298UPCB 78317UPCB).

Ecological information: these specimens differ from $S$. crassa in this study because they have rostrate to rostrate-rounded ends than just rounded ends. This species was recorded in $91 \%$ of the samples with higher values of abundance during the swamp and connected lake.

\section{Eunotiales}

Eunotiaceae

Eunotia bidens Ehrenberg, Abhandlungen der Königlichen Akademie der Wissenschaften zu Berlin, 413. 1843.

Figures 22-24 
Length: $20-72 \mu \mathrm{m}$; breadth: 7-11 $\mu \mathrm{m}$; striae: 9-14/10 $\mu \mathrm{m}$.

Material examined: Brazil. ParanÁ: Porto Rico, Ilha Mutum, sediment, 27-II-2012, Ruwer et al. (78282UPCB - 78294UPCB, 78298UPCB 78313UPCB, 78315UPCB - 78317UPCB).

Ecological information: periphytic species of lentic environments, occurring in acid waters, from oligotrophic to mesotrophic environments, and high temperature tolerant (Van Dam et al. 1994, Moro \& Fürstenberger 1997, Lange-Bertalot et al. 2011, Faustino et al. 2016), associated with bryophytes in marsh environments (Furey et al. 2011). This species was registered in $76 \%$ of the samples, during the periods of lake and transition, but its abundance was greater during the swamp and lake.

Eunotia cf. deformis Metzeltin \& Lange-Bertalot in Lange-Bertalot, Iconographia Diatomologica, 5: 57, pl. 16: figs. 9-11, 1998.

Figures 13-15, 70-71

Length: 19-62 $\mu \mathrm{m}$; breadth: 7-9 $\mu \mathrm{m}$; striae: 9-12/10 $\mu \mathrm{m}$.

Material examined: Brazil. Paraná: Porto Rico, Ilha Mutum, sediment, 27-II-2012, Ruwer et al. (78282UPCB - 78285UPCB, 78287UPCB 78288UPCB, 78291UPCB - 78292UPCB, 78297UPCB - 78302UPCB, 78305UPCB - 78306UPCB).

Ecological information: taxon registered for sediment of Brazilian environments (Metzeltin \& LangeBertalot 1998). The description of Eunotia deformis type in Metzeltin \& Lange-Bertalot (1998) presents a length variation compare to the population we were found, thus this taxon was maintained as Eunotia cf. deformis. This species was found in $47 \%$ of the samples, with higher abundances during the lake period.

Eunotia formica Ehrenberg, Abhandlungen der Königlichen Akademie der Wissenschaften zu Berlin, 1841: 414. 1843.

Figures 16-17, 69

Length: $30-110 \mu \mathrm{m}$; breadth: $7-11 \mu \mathrm{m}$; striae: $10-12 / 10 \mu \mathrm{m}$.

Material examined: Brazil. Paraná: Porto Rico, Ilha Mutum, sediment, 27-II-2012, Ruwer et al. (78282UPCB - 78284UPCB, 78286UPCB 78293UPCB, 78295UPCB - 78306UPCB).

Ecological information: species with broad geographical distribution, intolerant of pollution
(Bere \& Mangadze 2014), of benthic habitat, present in lentic, humid environments or slow-flowing waters, occurring in oligotrophic to mesotrophic, acidic waters, tolerate to temperatures of 15 to $30{ }^{\circ} \mathrm{C}$ (Patrick \& Reimer 1966, Van Dam et al. 1994, Moro \& Fürstenberger 1997, Ortiz-Lerín \& Cambra 2007, Taylor et al. 2007). This species was found in $64 \%$ of the samples, during the swamp and transition period, but with greater abundances during the lake period.

Eunotia cf. intermedia (Krasske ex Hustedt) Nörpel \& Lange-Bertalot in Lange-Bertalot, Bibliotheca Diatomologica, 27: 32, 1993 E Eunotia pectinalis f. intermedia Krasske ex Hustedt in Rabenhorst's Kryptogamen Flora von Deutschland, Österreich und der Schweiz, 298, fig. 763 1-o, 1932.

Figures 18-19, 72-73

Length: 10-18.5 $\mu \mathrm{m}$; breadth: 2.2-2.4 $\mu \mathrm{m}$; striae: $12-18 / 10 \mu \mathrm{m}$.

Material examined: Brazil. Paraná: Porto Rico, Ilha Mutum, sediment, 27-II-2012, Ruwer et al. (78288UPCB, 78292UPCB - 78294UPCB, $78297 \mathrm{UPCB}$ - 78298UPCB, $78300 \mathrm{UPCB}$ 78312UPCB).

Ecological information: in the present study a population presents a variation of length smaller than the description of the species in other studies (Metzeltin \& Lange-Bertalot 1998), therefore, identified the specimens as E. cf. intermedia. Species found in oligotrophic and acid environments (Van Dam et al. 1994, Ortiz-Lerín \& Cambra 2007), was registered in $44 \%$ of the samples with greater abundance in the lake period.

Eunotia longicamelus Costa, Bicudo \& Wetzel, Bibliotheca Diatomologica, 64: 32, pl. 73: figs. 1-17; pl. 74: figs. 108; pl. 75: 105; pl. 76: 1-4. 2017.

Figures 22-24, 66-68

Length: 17.5-85 $\mu \mathrm{m}$; breadth: $4-7 \mu \mathrm{m}$; striae: $8-12 / 10 \mu \mathrm{m}$.

Material examined: Brazil. PARANÁ: Porto Rico, Ilha Mutum, periphyton, 12-IV-2016, Ruwer et al. (78280UPCB - 78281UPCB); sediment, 27-II-2012, Ruwer et al. (78282UPCB - 78311UPCB, 78313UPCB - 78315UPCB).

Ecological information: species erroneously identified as Eunotia camelus Ehrenberg in taxonomic and ecological studies (Costa et al. 2017). Planktonic species of lentic and lotic acid environments, 
but can be found in alkaline environments. They tolerate oligotrophic to mesotrophic conditions and temperatures of 15 to more than $30^{\circ} \mathrm{C}$ (Moro \& Fürstenberger 1997, Ortiz-Lerín \& Cambra 2007, Faustino et al. 2016). This species was found in $91 \%$ of samples, was found in all periods, with greater abundance during the lake period.

Eunotia major (Smith) Rabenhorst. Flora europaea algarum aquae dulcis et submarinae, $1: 72,1864 \equiv$ Himantidium majus Smith in A synopsis of the British Diatomaceae, 14, pl. XXXIII [33]: fig. 286, 1856. Figures 25-26, 77-79

Length: 42-107 $\mu \mathrm{m}$; breadth: 7.8-9 $\mu \mathrm{m}$; striae: $8-11 / 10 \mu \mathrm{m}$.

Material examined: Brazil. ParanÁ: Porto Rico, Ilha Mutum, sediment, 27-II-2012, Ruwer et al. (78282UPCB - $78301 \mathrm{UPCB}, 78303 \mathrm{UPCB}$ 78312UPCB, 78315UPCB - 78317UPCB).

Ecological information: periphytic species of oligotrophic and acid waters, found in lentic and lotic environments (Moreira-Filho et al. 1973). Taxon with $85 \%$ frequency, with higher values of abundance in the lake period.

Eunotia naegelii Migula, Kryptogamen-Flora von Deutschland, Deutsch-Österreich und der Schweiz, 203. 1905.

Figure 27

Length: $20-85 \mu \mathrm{m}$; breadth: $2.7-4.2 \mu \mathrm{m}$; striae: 20/10 $\mu \mathrm{m}$.

Material examined: Brazil. ParanÁ: Porto Rico, Ilha Mutum, periphyton, 12-IV-2016, Ruwer et al. (78280UPCB - 78281UPCB); sediment, 27-II-2012, Ruwer et al. (78289UPCB, 78294UPCB, 78296UPCB - 78298UPCB, 78300UPCB, 78305UPCB).

Ecological information: benthic species, adhered by mucilage foot, occurring in lentic, oligotrophic and acidic waters (Van Dam et al. 1994, Moro \& Fürstenberger 1997, Montoya-Moreno \& AguirreRamírez 2013). This species was found in $26 \%$ of the samples, with greater abundance for the current period.

Eunotia pseudosudetica Metzeltin, Lange-Bertalot, \& García-Rodríguez, Iconographia Diatomologica, 15: 57, pl. 24: figs. 15-18, 2005.

Figures 28-29, 74-76

Length: 15.8-45 $\mu \mathrm{m}$; breadth: 4-6.5 $\mu \mathrm{m}$; striae: $11-16 / 10 \mu \mathrm{m}$.
Material examined: Brazil. ParanÁ: Porto Rico, Ilha Mutum, periphyton, 12-IV-2016, Ruwer et al. (78280UPCB - 78281UPCB); sediment, 27-II-2012, Ruwer et al. (78282UPCB - 78316UPCB).

Ecological information: species registered in the Bicca et al. (2011) study, where the periphytic community was collected in environments which are characterized by slightly acidic and temperature variation of 14 to $29.8^{\circ} \mathrm{C}$. The taxon was reported by Faustino et al. (2016) in samples ranging from meso to supereutrophic conditions. E. pseudosudetica was registered in $97 \%$ of the samples, in all periods, but with greater abundance in the lake period.

Eunotia rabenhorstiana var. elongata (Patrick) Metzeltin \& Lange-Bertalot, Iconographia Diatomologica, 5: 76, pl. 64: figs. 1-13; pl. 65: figs. $17-19,1998$ = Desmogonium rabenhorstianum var. elongatum Patrick in Notulae Naturae, 3, fig. 1-3, 1940.

Figure 30

Length: 77-125 $\mu \mathrm{m}$; breadth: 5-7 $\mu \mathrm{m}$; striae: $16-18 / 10 \mu \mathrm{m}$.

Material examined: Brazil. Paraná: Porto Rico, Ilha Mutum, periphyton, 12-IV-2016, Ruwer et al. (78280UPCB - 78281UPCB); sediment, 27-II-2012, Ruwer et al. (78282UPCB, 78285UPCB, 78287UPCB - 78301UPCB, 78303UPCB, 78305UPCB).

Ecological information: we observe through the periphytic samples that the specimens form chains, this species was found in $61 \%$ of the samples, with higher values of abundance in the transition period.

Eunotia subarcuatoides Alles, Nörpel, \& LangeBertalot, Nova Hedwigia, 53: 188, pl. 4: figs. 1-36, 1991.

Figures 20-21

Length: 13-22 $\mu \mathrm{m}$, breadth: 3-5 $\mu \mathrm{m}$; striae: $16-20 / 10 \mu \mathrm{m}$.

Material examined: Brazil. ParanÁ: Porto Rico, Ilha Mutum, sediment, 27-II-2012, Ruwer et al. (78283UPCB - 78285UPCB, 78287UPCB, $78289 \mathrm{UPCB}$ - $78298 \mathrm{UPCB}, 78300 \mathrm{UPCB}$ 78303UPCB, 78305UPCB).

Ecological information: epiphytic species, occurring in acidic and oligotrophic environments (Van Dam et al. 1994, Ortiz-Lerín \& Cambra 2007). This species was found in $58 \%$ of the samples with greater abundance during the transition period. 

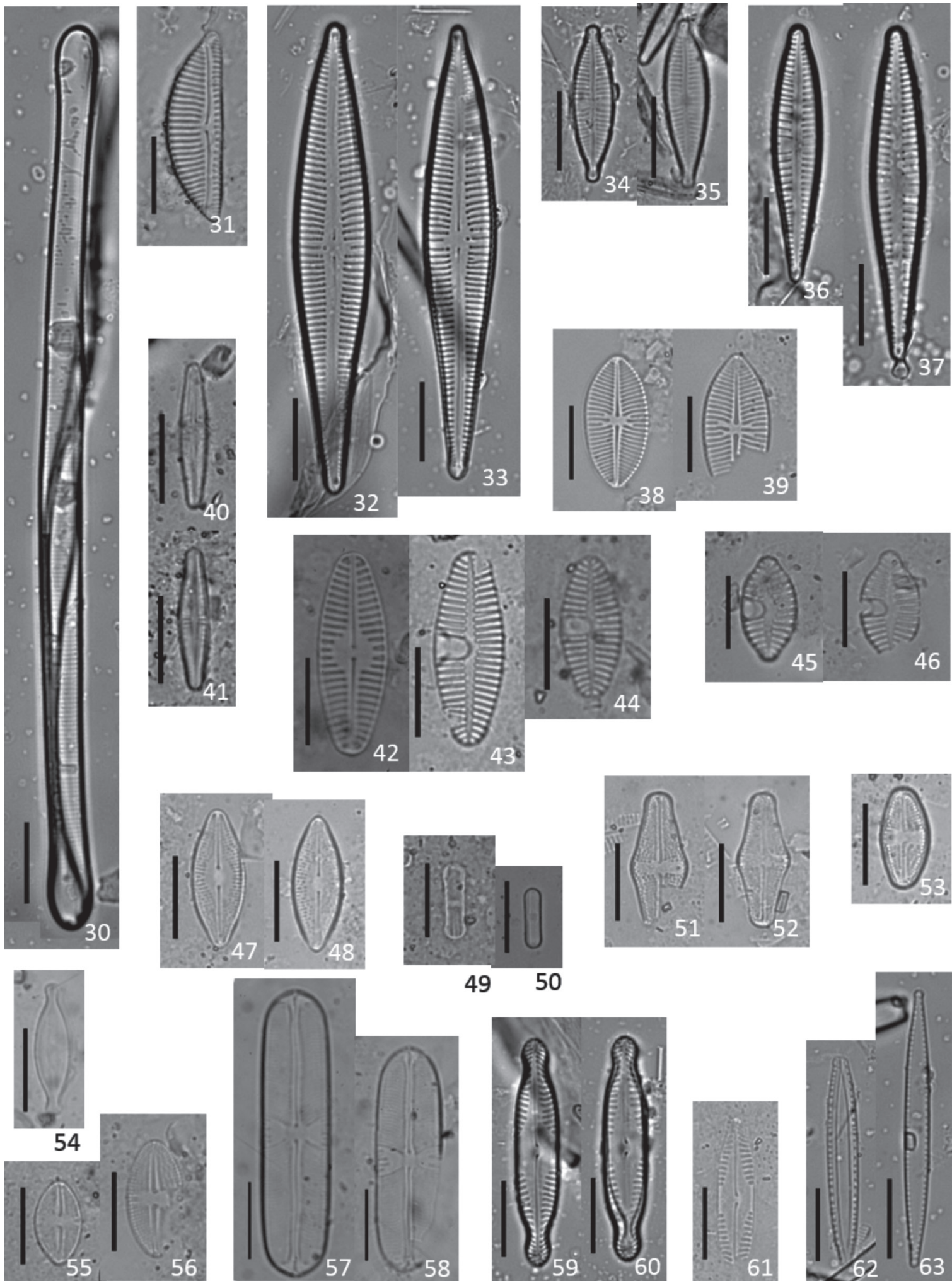

49
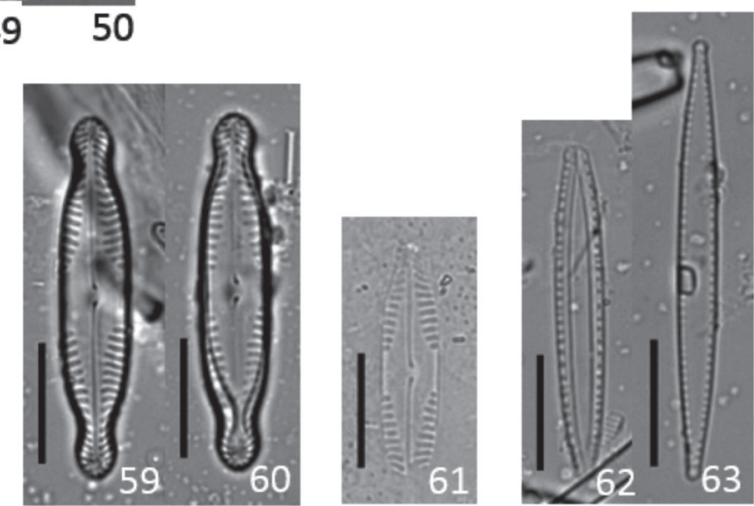

Figures 30-63. Diatom species from Mutum Island in in the upper Paraná river floodplain, Brazil (LM). 30. Eunotia rabenhorstiana var. elongata. 31. Encyonema silesiacum. 32-33. Gomphonema gracile. 34-35. Gomphonema lagenula. 36-37. Gomphonema sp. 1. 38-39. Placoneis ovillus. 40-41. Achnanthidium minutissimum. 42-44. Planothidium bagualensis. 45-46. Planothidium aff. rostratum. 47-48. Diadesmis confervacea. 49-50. Humidophila contenta. 51-52. Luticola hustedtii. 53. Luticola cf. simplex. 54. Nupela cf. bicapitata. 55-56. Luticola muticoides. 57-58. Sellaphora fusticulus. 59-60. Pinnularia brauniana. 61. Pinnularia sp. 1. 62-63. Nitzschia palea var. debilis. (Scale bar: $10 \mu \mathrm{m}$ ). 
Cymbellales

Gomphonemataceae

Encyonema silesiacum (Bleisch) Mann in Round, Crawford, \& Mann, Diatoms, 667, 1990 ECymbella silesiaca Bleisch in Algen Europa's, 1802, 1864.

Figures 31, 80

Length: $28-45 \mu \mathrm{m}$; breadth: $7.8-10 \mu \mathrm{m}$; striae: 9-12/10 $\mu \mathrm{m}$.

Material examined: Brazil. ParanÁ: Porto Rico, Ilha Mutum, periphyton, 12-IV-2016, Ruwer et al. (78280UPCB - 78281UPCB); sediment, 27-II-2012, Ruwer et al. (78282UPCB - 78303UPCB, 78305UPCB, 78314UPCB).

Ecological information: E. silesiacum presented periphytic habitat, but also can be found in plankton community, is an indicator of oligotrophic water, but can be found in eutrophic waters. It occurs in lentic and lotic waters, with acidic to alkaline $\mathrm{pH}$ and temperature ranging from 15 to more than $30^{\circ} \mathrm{C}$ (Van Dam et al. 1994, Moro \& Fürstenberger 1997, Marquardt \& Bicudo 2014). The taxon was reported by Faustino et al. (2016) and Almeida \& Bicudo (2014), studies of paleolimnological approach in Brazil, and was related with mesotrophic to supereutrophic conditions. This species was registered in $76 \%$ of the samples, with greater abundance in the transitional period.

Gomphonema gracile Ehrenberg, Die Infusionsthierchen als vollkommene Organismen, 217, pl. 18: fig. 3, 1938.

Figures 32-33, 81

Length: 24-64.3 $\mu \mathrm{m}$; breadth: 5.7-10.4 $\mu \mathrm{m}$; striae: $12-17 / 10 \mu \mathrm{m}$.

Material examined: Brazil. ParanÁ: Porto Rico, Ilha Mutum, periphyton, 12-IV-2016, Ruwer et al. (78280UPCB - 78281UPCB); sediment, 27-II-2012, Ruwer et al. (78283UPCB - 78284UPCB, 78287UPCB - 78298UPCB, 78303UPCB - 78304UPCB, 78313UPCB - 78314UPCB, 78316UPCB).

Ecological information: periphytic species from lentic environments, from oligotrophic to mesotrophic, neutral to alkaline waters, and tolerate temperatures from 15 to $30{ }^{\circ} \mathrm{C}$ (Valente-Moreira 1975, Contin \& Oliveira 1993, Van Dam et al. 1994, Moro \& Fürstenberger 1997, Marquardt \& Bicudo 2014, Faustino et al. 2016). This species was found in $61 \%$ of the samples with greater abundance in the current and transition periods.
Gomphonema lagenula Kützing, Die Kieselschaligen Bacillarien oder Diatomeen, 85, pl. 30: fig. 60, 1844.

Figures 34-35, 82

Length: 19-21 $\mu \mathrm{m}$; breadth: 5-6 $\mu \mathrm{m}$; striae: 17$18 / 10 \mu \mathrm{m}$.

Material examined: Brazil. Paraná: Porto Rico, Ilha Mutum, periphyton, 12-IV-2016, Ruwer et al. (78280UPCB - 78281UPCB); sediment, 27-II-2012, Ruwer et al. (78282UPCB - 78306UPCB).

Ecological information: this periphytic species was related to mesotrophic and eutrophic conditions in the study of Dunck et al. (2013) and Faustino et al. (2016), and related to urban and polluted environments by Moresco \& Rodrigues (2014). We have recorded the species in $79 \%$ of samples, it was absent only in the connected lake period, with higher values of abundance in the transition and current periods.

\section{Gomphonema sp. 1}

Figures 36-37, 83

Length: 22.5-44.9 $\mu \mathrm{m}$; breadth: 5.9-7.4 $\mu \mathrm{m}$; striae: $13-16 / 10 \mu \mathrm{m}$.

Material examined: Brazil. Paraná: Porto Rico, Ilha Mutum, periphyton, 12-IV-2016, Ruwer et al. (78280UPCB - 78281UPCB); sediment, 27-II-2012, Ruwer et al. (78283UPCB, 78287UPCB, 78291UPCB, $78295 \mathrm{UPCB}$ - 78298UPCB, $78300 \mathrm{UPCB}$ 78302UPCB, 78304UPCB, 78314UPCB).

Ecological information: we observe through the periphytic samples that the specimens presenting stalks for fixation. It was found in the current environment that presented a temperature of $27.9^{\circ} \mathrm{C}$, acidic to neutral $\mathrm{pH}$ and low oxygen value. Occurred in $41 \%$ of the samples, more abundant in the current period.

Placoneis ovillus Metzeltin, Lange-Bertalot \& GarcíaRodríguez, Iconographia Diatomologica, 15: 187, pl. 74: figs. 20-26, 2005.

Figures 38-39

Length: 14-24 $\mu \mathrm{m}$; breadth: 7-10 $\mu \mathrm{m}$; striae: 14$18 / 10 \mu \mathrm{m}$.

Material examined: Brazil. ParanÁ: Porto Rico, Ilha Mutum, sediment, 27/II/2012, Ruwer et al. (78283UPCB, 78285UPCB - 78286UPCB, 78289UPCB, 78291UPCB - 78293UPCB, 78298UPCB - 78304UPCB, 78306UPCB - 78317UPCB). 
Ecological information: this species was in $64 \%$ of the samples, with greater abundance in the period of the backwater.

Cocconeidales

Achnanthidiaceae

Achnanthidium minutissimum (Kützing) Czarnecki in Kockiolek, Proceedings of the 11th International Diatom Symposium, 17: 157, 1994 = Achnanthes minutissima Kützing in Synopsis diatomearum oder Versuch einer systematischen Zusammenstellung der Diatomeen, 578, fig. 54, 1833.

Figures 40-41

Length: $12.5-21 \mu \mathrm{m}$, breadth: $2.8-4 \mu \mathrm{m}$; inconspicuous striae.

Material examined: Brazil. ParanÁ: Porto Rico, Ilha Mutum, periphyton, 12-IV-2016, Ruwer et al. (78280UPCB); sediment, 27-II-2012, Ruwer et al. (78284UPCB -78289UPCB, 78291UPCB - $78293 \mathrm{UPCB}, 78295 \mathrm{UPCB}, 78299 \mathrm{UPCB}$ - $78301 \mathrm{UPCB}, 78304 \mathrm{UPCB}, 78313 \mathrm{UPCB}$ 78315UPCB).

Ecological information: the Achnanthidium minutissimum species complex is considered cosmopolitan and inhabits all freshwater habitats, mainly in lentic waters. Achnanthidium had a much wider tolerance range to various environmental factors. The Achnanthidium minutissimum is tolerant to a wide range of organic and inorganic pollution varying from oligotrophic to eutrophic conditions, although in some studies it is associated with low nutrients. It is tolerant at high temperatures (Moro \& Fürstenberger 1997, Ponader \& Potapova 2007, Potapova \& HaMilton 2007, Faustino et al. 2016). This species was in $52 \%$ of the samples, with higher values of abundance in the transition and backwater period.

Planothidium bagualensis Wetzel \& Ector, Phytotaxa, 156 (4): 201-210. 2014.

Figures 42-44, 84

Length: 12.9-30.8 $\mu \mathrm{m}$; breadth: $6-9 \mu \mathrm{m}$; striae: $10-16 / 10 \mu \mathrm{m}$.

Material examined: Brazil. ParanÁ: Porto Rico, Ilha Mutum, sediment, 27-II-2012, Ruwer et al. (78282UPCB - 78284UPCB, 78286UPCB 78288UPCB, 78290UPCB, 78292UPCB, 78297UPCB - 78317UPCB).
Ecological information: species erroneously identified as Planothidium lanceolatum (Brébisson ex Kützing) $\mathrm{H}$. Lange-Bertalot in Brazilian studies, found in the periphytic and phytoplanktonic community, mainly in lotic environments. Species with an optimum at mesotrophic waters, tolerating a large range of temperature (Burliga et al. 2005, Bes et al. 2012, Fontana \& Bicudo, 2012, Bartozek et al. 2013, Wetzel $\&$ Ector 2014). This species was recorded in $73 \%$ of the samples, with greater abundance in the lake phase.

Planothidium aff. rostratum (Østrup) Lange-Bertalot in Lange-Bertalot, Iconographia Diatomologica, 6: $279,1999 \equiv$ Achnanthes rostrata Østrup in Botanisk Tidsskrift 25: 35, pl. I: fig. 11, 1903.

Figures 45-46, 85

Length: 12-16 $\mu \mathrm{m}$; breadth: $6-8 \mu \mathrm{m}$; striae: $12-$ $16 / 10 \mu \mathrm{m}$.

Material examined: Brazil. ParanÁ: Porto Rico, Ilha Mutum, sediment, 27-II-2012, Ruwer et al. (78282UPCB - 78283 UPCB, 78292 UPCB - $78293 \mathrm{UPCB}, 78295 \mathrm{UPCB}, 78297 \mathrm{UPCB}$ 78317UPCB).

Ecological information: reported in studies by the synonym Achnanthes rostrata Østrup or by basionym Achnanthes lanceolata var. rostrata (Østrup) LangeBertalot. Species mainly found in the periphytic community, prostate, in lotic environments (Moro \& Fürstenberger 1997, Bartozek et al. 2013), also found in sedimentary samples in Brazil (Fontana \& Bicudo 2012). This species was found in $64 \%$ of the samples, with higher values of abundance during the lake and backwater periods.

Naviculales

Diadesmidaceae

Diadesmis confervacea Kützing, Die Kieselschaligen Bacillarien oder Diatomeen, 109, pl. 30: fig. 8, 1844.

Figures 47-48, 86-87

Length: 12-22 $\mu \mathrm{m}$; breadth: 5-8 $\mu \mathrm{m}$; striae: $12-14 / 10 \mu \mathrm{m}$.

Material examined: Brazil. PARANÁ: Porto Rico, Ilha Mutum, periphyton, 12-IV-2016, Ruwer et al. (78280UPCB - 78281UPCB); sediment, 27-II-2012, Ruwer et al. (78282UPCB - 78306UPCB, 78313UPCB, 78317UPCB).

Ecological information: benthic species that form long chains (observed in the periphytic samples), present in 
shallow water, wet and marshy environments. Occurs in eutrophic environments with high temperatures, acidic to alkaline waters (Cholnocky 1958, Hustedt 1966, Patrick \& Reimer 1966, Van Dam et al. 1994, Moro \& Fürstenberger 1997, Taylor et al. 2007, Torgan \& Santos 2008). This species had a broader distribution in a Brazilian study with sediment samples (Faustino et al. 2016) and was related to mesotrophic to supereutrophic conditions. This species was found in $85 \%$ of samples, showed greater abundance during the transition period.

Humidophila contenta (Grunow) Lowe, Kociolek, Johansen, Van de Vijver, Lange-Bertalot \& Kopalová, Diatom Research, 29:357, 2014 =Navicula contenta Grunow in Synopsis des Diatomées de Belgique, $109,1885$.

Figures 49-50, 88-89

Length: 7-15 $\mu \mathrm{m}$; breadth: 2.2-3 $\mu \mathrm{m}$; inconspicuous striae.

Material examined: Brazil. ParanÁ: Porto Rico, Ilha Mutum, sediment, 27-II-2012, Ruwer et al. (78282UPCB - 78311 UPCB, 78313 UPCB 78317UPCB).

Ecological information: recently transferred of the Diadesmis to Humidophila genus (Lowe et al. 2014). Reported in paleolimnological studies in Brazilian environments (Costa-Böddeker et al. 2012, Fontana $\&$ Bicudo 2012), related to aerophilic habit and lownutrient. Benthic species, such as $D$. confervaceae, occur in shallow waters and wet environments. It tolerates low luminosity and temperatures from 15 to $30{ }^{\circ} \mathrm{C}$, indicate mesotrophic to eutrophic environments and acid to alkaline waters (Van Dam et al. 1994, Moro \& Fürstenberger 1997, Lobo et al. 2004, Taylor et al. 2007). Frequently in $91 \%$ of the samples with higher values of abundance during the transition period.

Luticola hustedtii Levkov, Metzeltin \& Pavlov, Diatoms of Europe, 7: 131, pl. 24: fig. 49; pl. 166: figs. 24-37; pl. 168: figs. 7-26; pl. 170: figs. $1-7,2013$.

Figures 51-52, 90

Length: 10.5-25 $\mu \mathrm{m}$; breadth: 5.8-8 $\mu \mathrm{m}$; inconspicuous striae.

Material examined: Brazil. ParanÁ: Porto Rico, Ilha Mutum, periphyton, 12-IV-2016, Ruwer et al. (78280UPCB); sediment, 27-II-2012, Ruwer et al. (78282UPCB - 78296UPCB, 78300UPCB - $78306 \mathrm{UPCB}, 78313 \mathrm{UPCB}, 78315 \mathrm{UPCB}$, 78317UPCB).
Ecological information: species of the genus Luticola are common in moist and swampy soils (Van de Vijver et al. 2002, Lowe et al. 2007). Luticola hustedtii was reported in Faustino et al. (2016) in sediment samples and was related to past oligotrophic conditions. This taxon was found in the epiphyton of slightly acidic waters in Straube et al. (2017). This species was found in $76 \%$ of samples, was abundant in the swamp and transition periods.

Luticola muticoides (Hustedt) Mann in Round, Crawford, \& Mann, Diatoms, 671, $1990 \equiv$ Navicula muticoides Hustedt in Süsswasser-Diatomeen, 82, pl. 4: figs 33-36, 1949.

Figures 55-56, 91

Length: 10-23 $\mu \mathrm{m}$; breadth: 6-9.5 $\mu \mathrm{m}$; inconspicuous striae.

Material examined: Brazil. Paraná: Porto Rico, Ilha Mutum, sediment, 27-II-2012, Ruwer et al. (78282UPCB - $78298 \mathrm{UPCB}, 78300 \mathrm{UPCB}$ - 78302UPCB, $78304 \mathrm{UPCB}-78305 \mathrm{UPCB}$, 78313UPCB, 78315UPCB).

Ecological information: occurring lotic and lentic environments, in acidic to alkaline waters (Moro \& Fürstenberger 1997). It was found in $70 \%$ of the samples with higher values of abundance during the transition.

Luticola cf. simplex Metzeltin, Lange-Bertalot \& García-Rodríguez, Iconographia Diatomologica, 15: 116, pl. 87: figs 1-9, 2005.

Figures 53, 92

Length: 11-16 $\mu \mathrm{m}$; breadth: 5.2-6 $\mu \mathrm{m}$; inconspicuous striae.

Material examined: Brazil. PARAnÁ: Porto Rico, Ilha Mutum, sedimento, 27-II-2012, Ruwer et al. (78282UPCB - 78317UPCB).

Ecological information: this species was found in sediment samples of Faustino et al. (2016), where this taxon had a broad distribution range, related with oligotrophic and eutrophic conditions. Taxon occurring in $94 \%$ of samples with higher values of abundance during a transition and swamp periods.

\section{Brachysiraceae}

Nupela cf. bicapitata (Hustedt) Tremarin \& Ludwig, Fottea, 15(1): 78, $2015 \equiv$ Achnanthes bicapitata Hustedt in Botaniska Notiser, 386, figs. 68-71, 1952.

Figures 54, 93 
Length: $18-20 \mu \mathrm{m}$; breadth: 5-6 $\mu \mathrm{m}$; striae: $50 / 10 \mu \mathrm{m}$.

Material examined: Brazil. ParanÁ: Porto Rico, Ilha Mutum, periphyton, 12-IV-2016, Ruwer et al. (78280UPCB - 78281UPCB); sediment, 27-II-2012, Ruwer et al. (78283UPCB - 78284UPCB, 78286UPCB - 78287UPCB, 78291UPCB - 78299UPCB, 78305UPCB, 78314UPCB).

Ecological information: taxon registered for the first time in Brazil by Tremarin et al. (2015), however, we consider our specimens as Nupela cf. bicapitata due to the smaller population length. This species was found in all periods, however, presented higher values of abundance in the period of the backwater.

Sellaphoraceae

Sellaphora fusticulus (Østrup) Lange-Bertalot, Iconographia Diatomologica, 9:216,2000 $\equiv$ Navicula fusticulus Østrup in Danske Diatoméer, 36; pl. 1, fig. 19, 1910.

Figures 57-58

Length: $32-46 \mu \mathrm{m}$; breadth: $8-9 \mu \mathrm{m}$; inconspicuous striae.

Material examined: Brazil. ParanÁ: Porto Rico, Ilha Mutum, periphyton, 12-IV-2016, Ruwer et al. (78280UPCB - 78281UPCB); sediment, 27-II-2012, Ruwer et al. (78282UPCB - 78283UPCB, 78286UPCB - 78303UPCB, 78313UPCB - 78314UPCB).

Ecological information: present in $70 \%$ of the samples with higher values of abundance during the transition period.

Pinnulariaceae

Pinnularia brauniana (Grunow) Studnicka in Wein, Verhandlungen der Kaiserlich-Königlichen Zoologisch-Botanischen Gesellschaft, 38: 737, 1888 = Navicula brauniana Grunow in Atlas der Diatomaceen-kunde, pl. 45: figs 77-78, 1876

Figures 59-60, 94

Length: 28.1-50 $\mu \mathrm{m}$; breadth: 5.6-8.3 $\mu \mathrm{m}$; striae: $11-15 / 10 \mu \mathrm{m}$.

Material examined: Brazil. ParanÁ: Porto Rico, Ilha Mutum, periphyton, 12-IV-2016, Ruwer et al. (78280UPCB - 78281UPCB); sediment, 27-II-2012, Ruwer et al. (78282UPCB - 78283UPCB, 78285UPCB - 78298UPCB, 78300UPCB - $78301 \mathrm{UPCB}$, 78316UPCB).
Ecological information: P. brauniana was in $61 \%$ of the samples with greater abundance in the current and transition periods.

\section{Pinnularia sp. 1}

Figures 61, 95

Length: 19-23 $\mu \mathrm{m}$; breadth: 4.8-5 $\mu \mathrm{m}$; striae: $14-16 / 10 \mu \mathrm{m}$.

Material examined: Brazil. Paraná: Porto Rico, Ilha Mutum, sedimento, 27-II-2012, Ruwer et al. (78288UPCB - 78298UPCB, 78300UPCB, 78302UPCB).

Ecological information: the species was found in $38 \%$ of the samples, with greater abundance during the transition period.

Bacillariales

Bacillariaceae

Nitzschia palea var. debilis (Kützing) Grunow, Kongliga Svenska Vetenskaps-Akademiens Handligar, 17(2): 96, 1880 $\equiv$ Synedra debilis Kützing in Die Kieselschaligen Bacillarien oder Diatomeen, 65, pl. 3: fig. XLV, 1844.

Figures 62-63

Length: 23-49.3 $\mu \mathrm{m}$; breadth: 3.1-5.2 $\mu \mathrm{m}$; fibulae: $11-13 / 10 \mu \mathrm{m}$.

Material examined: Brazil. Paraná: Porto Rico, Ilha Mutum, periphyton, 12-IV-2016, Ruwer et al. (78280UPCB - 78281UPCB); sediment, 27-II-2012, Ruwer et al. (78285UPCB, 78291UPCB, 78295UPCB, 78297UPCB, 78301UPCB, 78314UPCB).

Ecological information: found in periphytic and plankton community. Occurring in lentic, oligotrophic and eutrophic environments, but prefer clean or only slightly polluted waters (Tomas \& Sabater 1985, Gasse 1987, Vyverman 1991, Van Dam et al. 1994, Moro \& Fürstenberger 1997, Potapova \& Charles 2007, Trobajo et al. 2009). A frequency of $23 \%$ with greater abundance in the current period.

Among the 31 taxa addressed, all were found in the sediment samples and 15 were present in the periphyton community, 16 were exclusive in the sediment (table 2). It is important to highlight the great exclusive diversity of diatoms that can be found in sediments. Along the temporal variation, there are consequently physical and chemical, biological and geomorphological changes in the environment. In temporal ecology, these factors and the habitat control 
Table 2. Distribution and abundance of diatom species in the studied periods, Mutum island in in the upper Paraná river floodplain, Brazil (hatched area according to range of abundance values; dark gray - $30 \%$ to $100 \%$, gray - $20 \%$ to $30 \%$, light gray $-5 \%$ to $20 \%$, white - $0 \%) *$ New records for the State of Paraná according to Tremarin et al. 2009, Bertolli et al. 2010, Faria et al. 2010, Silva et al. 2010, Santos et al. 2011, Moresco et al. 2011, Bartozek et al. 2013 - Table organized according to Round et al. 1990.

\begin{tabular}{|c|c|c|c|c|c|}
\hline Taxa & $\begin{array}{c}\text { Periphyton } \\
(2016)\end{array}$ & Swamp & $\begin{array}{c}\text { Transition } \\
(>300 \text { years })\end{array}$ & $\begin{array}{c}\text { Lake } \\
(>760 \text { years })\end{array}$ & $\begin{array}{c}\text { Backwater } \\
\text { (>920 years) }\end{array}$ \\
\hline \multicolumn{6}{|l|}{ Aulacoseira italica } \\
\hline \multicolumn{6}{|l|}{ Staurosirella crassa } \\
\hline \multicolumn{6}{|l|}{ Staurosirella crassa mp. I } \\
\hline \multicolumn{6}{|l|}{ Eunotia bidens } \\
\hline \multicolumn{6}{|l|}{ Eunotia cf. deformis } \\
\hline \multicolumn{6}{|l|}{ Eunotia formica } \\
\hline \multicolumn{6}{|l|}{ Eunotia $\mathrm{cf}$. intermedia } \\
\hline \multicolumn{6}{|l|}{ Eunotia longicamelus * } \\
\hline \multicolumn{6}{|l|}{ Eunotia major } \\
\hline \multicolumn{6}{|l|}{ Eunotia naegelli } \\
\hline \multicolumn{6}{|l|}{ Eunotia pseudosudetica } \\
\hline \multicolumn{6}{|c|}{ Eunotia rabenhorstiana var. elongata } \\
\hline \multicolumn{6}{|l|}{ Eunotia subarcuatoides } \\
\hline \multicolumn{6}{|l|}{ Encyonema silesiacum } \\
\hline \multicolumn{6}{|l|}{ Gomphonema gracile } \\
\hline \multicolumn{6}{|l|}{ Gomphonema lagenula } \\
\hline \multicolumn{6}{|l|}{ Gomphonema sp. 1} \\
\hline \multicolumn{6}{|l|}{ Placoneis ovillus } \\
\hline \multicolumn{6}{|l|}{ Achnanthidium minutissimum } \\
\hline \multicolumn{6}{|l|}{ Planothidium bagualensis * } \\
\hline \multicolumn{6}{|l|}{ Planothidium aff. rostratum } \\
\hline \multicolumn{6}{|l|}{ Diadesmis confervaceae } \\
\hline \multicolumn{6}{|l|}{ Humidophila contenta } \\
\hline \multicolumn{6}{|l|}{ Luticola hustedtii * } \\
\hline \multicolumn{6}{|l|}{ Luticola muticoides } \\
\hline \multicolumn{6}{|l|}{ Luticola cf. simplex } \\
\hline \multicolumn{6}{|l|}{ Nupela cf. bicapitata } \\
\hline \multicolumn{6}{|l|}{ Sellaphora fusticulus } \\
\hline \multicolumn{6}{|l|}{ Pinnularia brauniana } \\
\hline \multicolumn{6}{|l|}{ Pinnularia sp. 1} \\
\hline Nitzschia palea var. debilis & & & & & \\
\hline
\end{tabular}

the establishment and colonization of the species. The ability of populations to compete and persist in a habitat depends on how well species adapt to develop under specific environmental conditions (Patrick \& Reimer 1966).

Each period was recognized in the record through the peculiar characteristics of each phase in the sedimentological material (Leli et al. 2017). In this research, some species presented greater abundance for each geomorphological period (backwater, lake, transition, and swamp). However, in the channel period (726-903 cal yr BP) was not found diatoms. The great dominance of periphytic species in swamp and transition periods could indicate the presence and abundance of macrophytes and vegetation located in the coastal region of the aquatic environment 

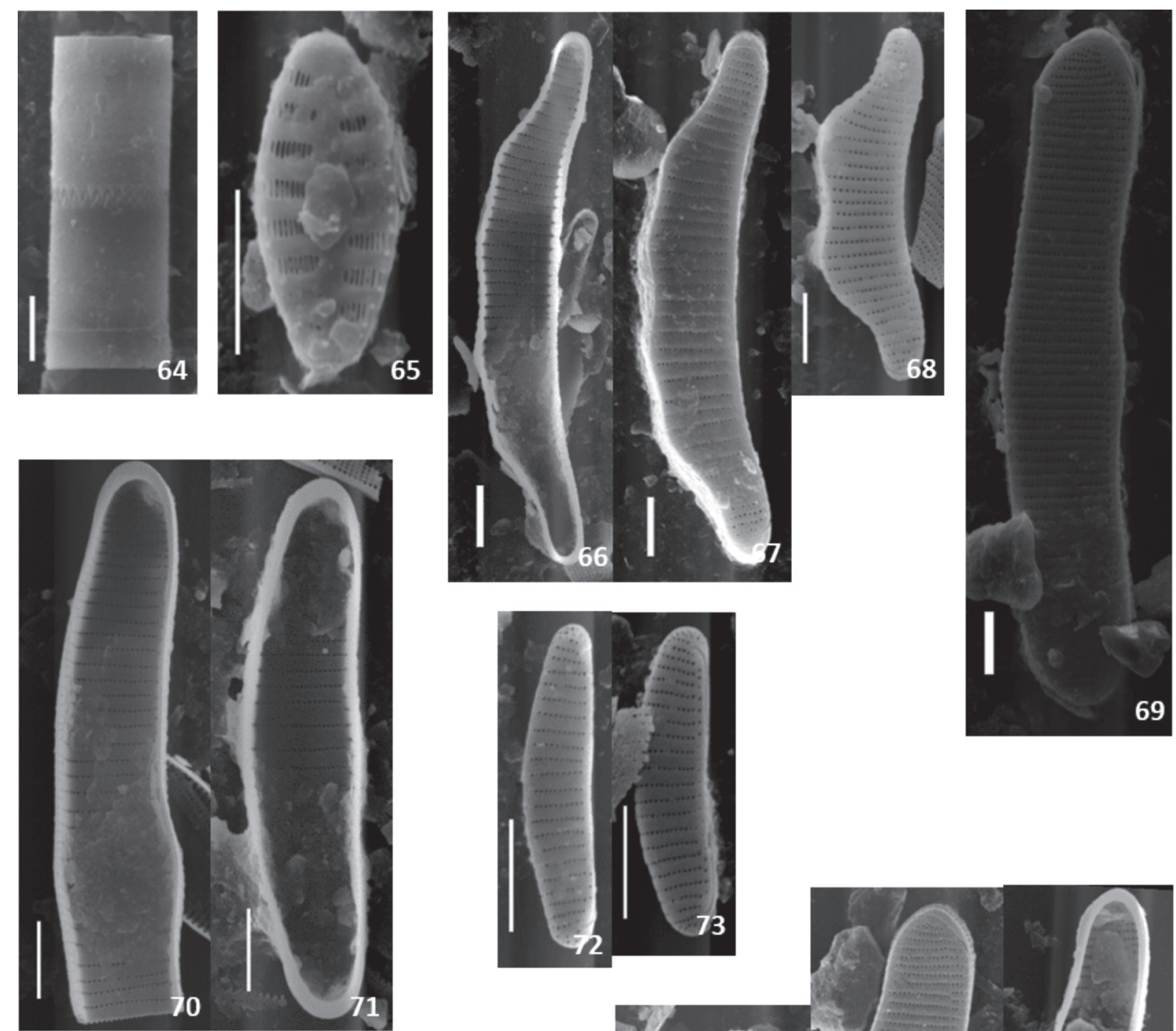

69
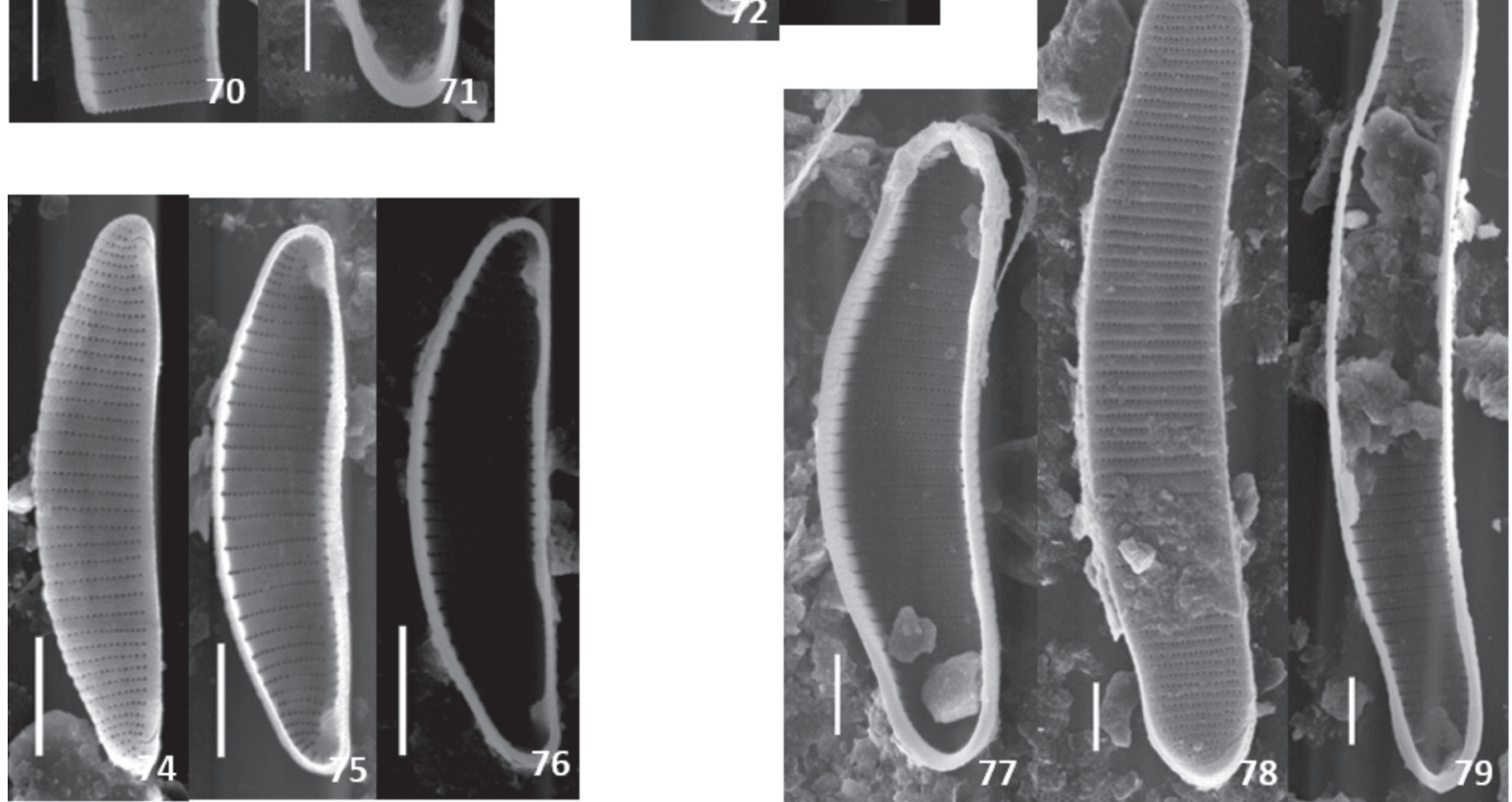

Figures 64-79. Diatom species from Mutum Island (SEM).island in in the upper Paraná river floodplain, Brazil (SEM). 64. Aulacoseira italica. 65. Staurosirella crassa. 66-68. Eunotia longicamelus. 69. Eunotia formica. 70-71. Eunotia cf. deformis (71 - internal valvar view). 72-73. Eunotia cf. intermedia. 74-76. Eunotia pseudosudetica (75 and 76 - internal valvar view). 77-79. Eunotia major (77 and 79 - internal valvar view). (Scale bar: $5 \mu \mathrm{m}$ ). 

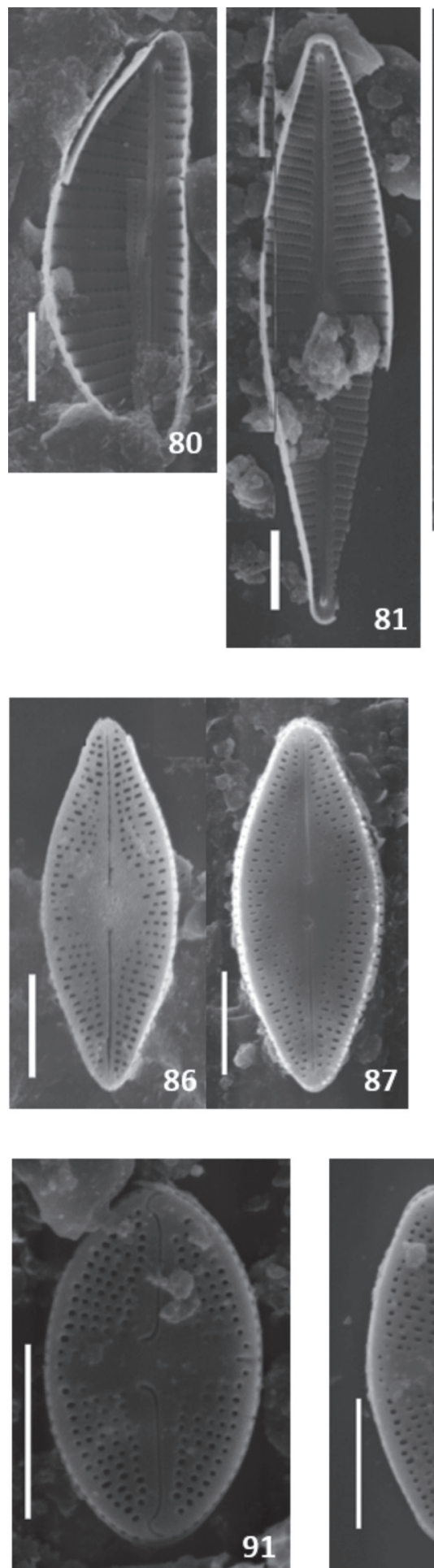
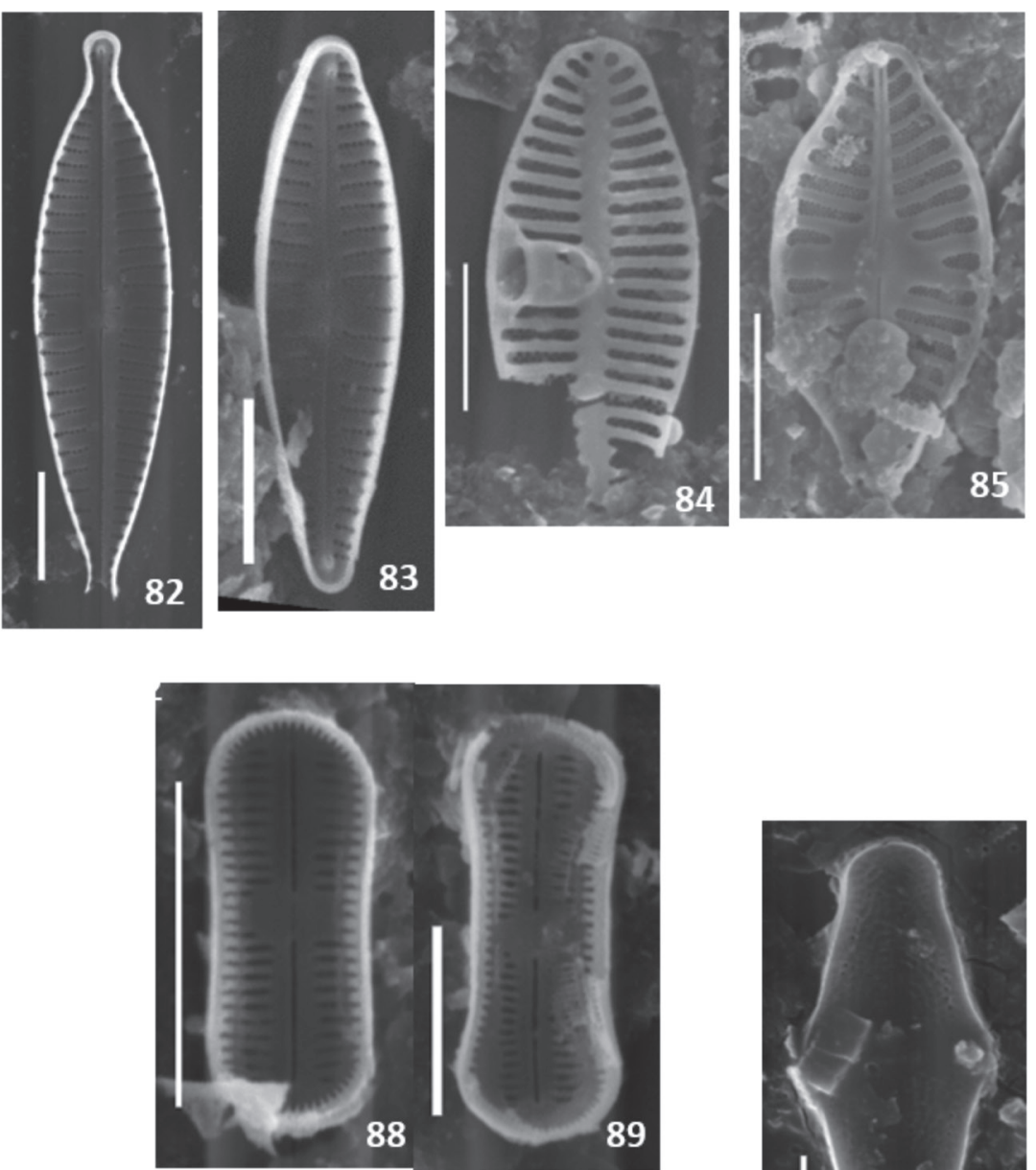

89
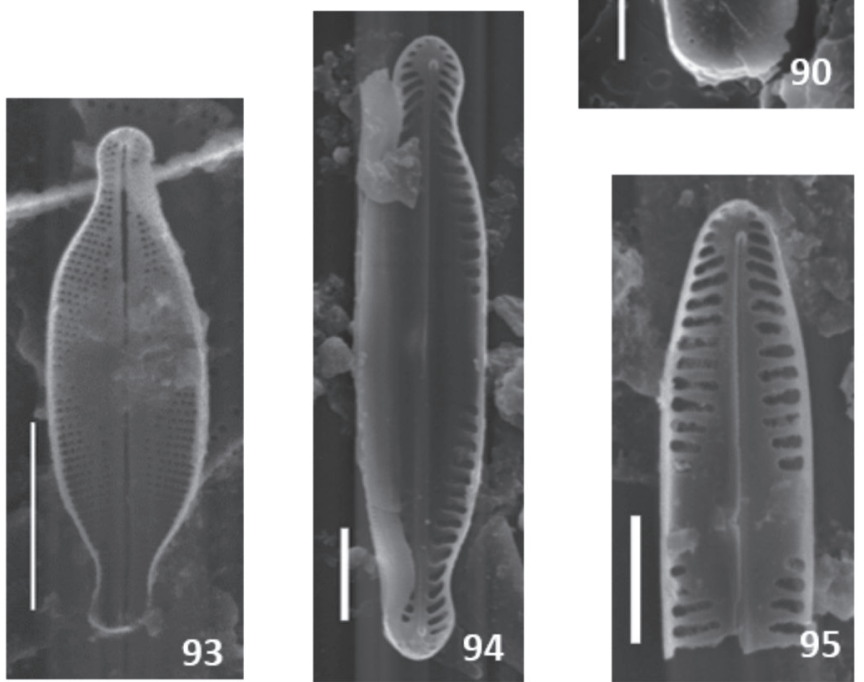

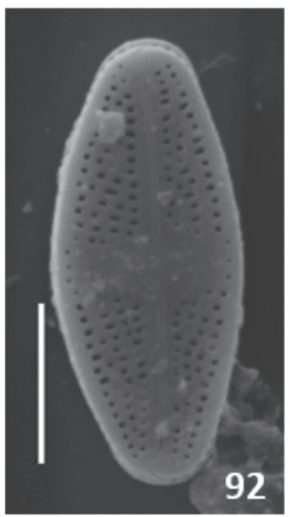

Figures 80-95. Diatom species from Mutum Island (SEM).island in in the upper Paraná river floodplain, Brazil (SEM). 80. Encyonema silesiacum (internal valvar view). 81. Gomphonema gracile (internal valvar view). 82. Gomphonema lagenula (internal valvar view). 83. Gomphonema sp. 1 (internal valvar view). 84. Planothidium bagualensis (internal valvar view). 85. Planothidium aff. rostratum (internal valvar view). 86-87. Diadesmis confervaceae. 88-89. Humidophila contenta (internal valvar view). 90. Luticola hustedtii. 91. Luticola muticoides. 92. Luticola $\mathrm{cf}$ simplex. 93. Nupela cf. bicapitata (internal valvar view). 94. Pinnularia brauniana (internal valvar view). 95. Pinnularia subcapitata (internal valvar view). (Scale bar: $5 \mu \mathrm{m}$ ). 
(Felisberto \& Rodrigues 2010). The occurrence of some species as Diadesmis confervacea, Humidophila contenta, Luticola muticoides, Luticola cf. simplex in transition and swamp periods indicated shallow water environments, wet soils and marsh environments (Van de Vijver et al. 2002, Lowe et al. 2007, Torgan $\&$ Santos 2008). The great contribution of species of the order Naviculales in the transition period can be explained by these taxa being abundant in marshy environments as reported in the study of Vijayan \& Ray (2016).

The lake period has a predominance of Eunotiaceae species (as Eunotia longicamelus, Eunotia major), which indicates a decrease of the $\mathrm{pH}$, conductivity, and nutrients (Vélez et al. 2005). The occurrence of species belonging to the family Fragilariaceae (as Staurosirella crassa), in the backwater can be explained by the affinity of these taxa to unstable environments with continuous changes, characteristics that can be provided in a connected lake (Haworth 1976, Thomaz et al. 1997). Our results show a taxonomic contribution of diatoms to the region due to the three new registrations (E. longicamelus, Planothidium bagualensis and Luticola hustedtii). We showed the importance of palaeolimnological studies to increase information about aquatic biodiversity and also provided the first palaeolimnological research for a Brazilian floodplain.

\section{Acknowledgments}

We thank the Programa de Pós-graduação em Ecologia de Ambientes Aquáticos Continentais (PEA), the Núcleo de Pesquisas em Limnologia, Ictiologia e Aquicultura (Nupélia) and the Complexo de Centrais de Apoio à Pesquisa (COMCAP) from the Universidade Estadual de Maringá (UEM) for supplying the infrastructure. We would like to thank the Coordenação de Aperfeiçoamento de Pessoal de Nível Superior (CAPES) for providing a master scholarship to Daiane Trevisan Ruwer, and the Conselho Nacional de Desenvolvimento Científico e Tecnológico (CNPq) for a research productivity scholarship to Liliana Rodrigues. We thank Bárbara Dunck for the first corrections of the manuscript. We also thank the Grupo de Estudos do Meio Ambiente (GEMA/UEM) and Dr. José Cândido Stevaux for providing samples and data.

\section{Literature cited}

Almeida, P.D. \& Bicudo, D.C. 2014. Diatomáceas planctônicas e de sedimento superficial em represas de abastecimento da Região Metropolitana de São Paulo, SP, Sudeste do Brasil. Hoehnea 41: 187-207.
Almeida, P.D., Wetzel, C.E., Morales, E.A., Ector, L. \& Bicudo, D.C. 2015. Staurosirella acidophila sp. nov., a new araphid diatom (Bacillariophyta) from southeastern Brazil: ultrastructure, distribution and autecology. Cryptogamie, Algologie 36: 255-270.

Bartozek, E., Bueno, N.C., Ludwig, T.A.V., Tremarin, P., Nardelli, M. \& Rocha, A. 2013. Diatoms (Bacillariophyceae) of Iguaçu National Park, Foz do Iguaçu, Brazil. Acta Botânica Brasílica 27: 108-123.

Battarbee, R.W. 1986. Diatom analysis. In: B.E. Berglund (ed.). Handbook of Holocene Paleoecology and Paleohydrology, London, Wiley and Sons, pp. 527-570.

Battarbee, R.W. 1999. The importance of palaeolimnology to lake restoration. Hydrobiologia 395: 149-159.

Battarbee, R.W., Jones, V.J., Flower, R.J., Cameron, N.G. \& Bennion, H. 2001. Diatoms. In: J.P. Smol, H.J.B. Birks \& W.M. Last (eds.). Tracking Environmental Change Using Lake Sediments. The Netherlands, Kluwer Academic Publishers, Volume 3: Terrestrial, Algal, and Siliceous Indicators, pp. 155-202.

Bere, T. \& Mangadze, T. 2014. Diatom communities in streams draining urban areas: community structure in relation to environmental variables. Tropical Ecology 55: 271-281.

Bertolli, L.M., Tremarin, P.I. \& Ludwig, T.A.V. 2010. Diatomáceas perifíticas em Polygonum hydropiperoides Michaux, reservatório do Passaúna, Região Metropolitana de Curitiba, Paraná, Brasil. Acta Botânica Brasílica, 24: 1065-1081.

Bes, D., Ector, Luc., Torgan, L.C. \& Lobo, E.A. 2012. Composition of the epilithic diatom flora from a subtropical river, Southern Brazil. Iheringia, Série Botânica, 67: 93-125.

Bicca, A.B., Torgan, L.C. \& Santos, C.B. 2011. Eunotiaceae (Eunotiales, Bacillariophyta) em ambientes lacustres na Planície Costeira do Sul do Brasil. Brazilian Journal of Botany 34: 1-19.

Bichoff, A., Osorio, N.C., Dunck, B. \& Rodrigues, L. 2016. Periphytic algae in a floodplain lake and river under low water conditions. Biota Neotropica, 16:3, e20160159.

Bicudo, D.C., Tremarin, P.I., Almeida, P.D., ZorzalAlmeida, S., Wengrat, S., Faustino, S.B., Costa, L.F., Bartozek, E.C.R., Rocha, A.C.R., Bicudo, C.E.M. \& Morales, E.A. 2016. Ecology and distribution of Aulacoseira species (Bacillariophyta) in tropical reservoirs from Brazil. Diatom Research 31: 199-215.

Bicudo, C.E.M. \& Menezes, M. 2017. Gêneros de algas de águas continentais do Brasil: chave para identificação e descrições. São Carlos, RiMa, pp.1-552.

Biolo, S. \& Rodrigues, L. 2013. Structure of the periphytic algae associated with a floating macrophyte in an open lake on the Upper Paraná river floodplain, Brazil. Acta Scientiarum - Biological Sciences 35: 513-519. 
Bradbury, J.P. 1975. Diatom stratigraphy and human settlement in Minnesota. Geological Society of America Special Papers, 171: 1-74.

Burliga, A.L., Torgan, L.C., Nobrega, E.A., Beaumord, A.C., Costa, C.O.\& Wamauti, D.V. 2005. Diatomáceas epilíticas do rio Itajaí-Mirim, Santa Catarina, Brasil. Acta Scientiarum - Biologica Sciences 27: 415-421.

Cholnocky, B.J. 1958. Beiträge zur Kenntnis der südafrikanischen Diatomeenflora. II. Einige Gewässer im Waterberg- Gebiet, Transvaal. Portugalie Acta Biológica 6: 99-153.

Contin, L.F. \& Oliveira, R.J.M. 1993. Diatomáceas (Chrysophyta - Bacillariophyceae) em águas termais: Lagoa Santa - Município de Itajá - Goiás, pp. 7-35. In: I.F.P. Campos (ed.). Flora dos Estados de Goiás e Tocantins, criptógamos. v.2, n. 1, Goiânia, Editora da UFG-EDUFG.

Costa-Böddeker, S., Bennion, H., Jesus, T.A.D.E, Albuquerque, A.L.S., Figueira, R.C.L. \& Bicudo, D.C. 2012. Paleolimnological inferred eutrophication of a shallow, tropical, urban reservoir in southeast Brazil. Journal of Paleolimnology 48: 751-766.

Costa, L.F., Wetzel, C.E., Lange-Bertalot, H., Ector, L. \& Bicudo, D.C. 2017. Taxonomy and ecology of Eunotia species (Bacillariophyta) in southeastern Brazilian reservoirs. Bibliotheca Diatomologica 64: 1-302.

Dong, X., Bennion, H., Battarbee, R.W., Yang, X., Yang, H. \& Liu, E. 2008. Tracking eutrophication in Taihu Lake using diatom record: potential and problems. Journal of Paleolimnology 40: 413-429.

Douglas, M.S.V. \& Smol, J.P. 1999. Freshwater diatoms as indicators of environmental change in the High Arctic. In: E.F. Stoermer \& J.P. Smol (eds.).The Diatoms: Applications for the Environmental and Earth Sciences. Cambridge University Press, Cambridge, pp. 227-244

Dunck, B., Nogueira, I.S. \& Souza, M.G.M. 2012. Planktonic diatoms in lotic and lentic environments in the Lago dos Tigres hydrologic system (Britânia, Goiás, Brazil): Coscinodiscophyceae and Fragilariophyceae. Brazilian Journal of Botany 35: 181-193.

Dunck, B., Nogueira, I.S. \& Felisberto, S.A. 2013. Distribution of periphytic algae in wetlands (Palm swamps, Cerrado), Brazil. Brazilian Journal of Biology 73: 331-346.

Estepp, L.R. \& Reavie, E.D. 2015. The ecological history of Lake Ontario according to phytoplankton. Journal of Great Lakes Research 41: 669-687.

Faria, de M.D., Tremarin, P.I. \& Ludwig, T.A.V. 2010. Diatomáceas perifíticas da Represa Itaqui, São José dos Pinhais, Paraná: Fragilariales, Eunotiales, Achnanthales e Gomphonema Ehrenberg. Biota Neotropica 10: 415-427.
Faustino, S.B., Fontana, L., Bartozek, E.C.R., Bicudo, C.E.M. \& Bicudo, D.C. 2016. Composition and distribution of diatom assemblages from core and surface sediments of a water supply reservoir in Southeastern Brazil. Biota Neotropica 16: e20150129.

Felisberto, S.A. \& Rodrigues, L. 2010. Periphytic algal community in artificial and natural substratum in a tributary of the Rosana reservoir (Corvo Stream, Paraná State, Brazil). Acta Scientiarum. Biological Sciences 32: 373-385.

Fernandez, O.V.Q., Santos, M.L. \& Stevaux, J.C. 1993. Evolução e características faciológicas de um conjunto de ilhas no rio Paraná, região de Porto Rico (PR). Boletim de Geografia - UEM, Ano 11, n.1.

Ferrario, M.E., Sar, E.A. \& Sala, S.E. 1995. Metodología básica para el estudio del fitoplancton con especial referencia a las diatomeas. In: K. Alveal, \& M.E. Ferrario (eds.). Manual de métodos ficológicos. Ediciones Universidad de Concepción, Concepción, Chile, pp. 1-23.

Fontana, L. \& Bicudo, D.C. 2009. Diatomáceas (Bacillariophyceae) de sedimentos superficiais dos reservatórios em cascata do Rio Paranapanema (SP/ PR, Brasil): Coscinodiscophyceae e Fragilariophyceae. Hoehnea 36: 375-386.

Fontana, L. \& Bicudo, D.C. 2012. Biodiversidade e distribuição das diatomáceas (Bacillariophyceae) de sedimentos superficiais nos reservatórios em cascata do rio Paranapanema (SP/PR, Brasil). Hoehnea 39: 587-612.

Fontana, L., Albuquerque, A.L.S., Brenner, M., Bonotto, D.M., Sabaris, T.P.P., Pires, M.A.F., Cotrim, M.E.B. \& Bicudo, D.C. 2014. The eutrophication history of a tropical water supply reservoir in Brazil. Journal of Paleolimnology 51: 29-43.

Furey, P.C., Lowe, R.L. \& Johansen, J.R. 2011. Eunotia Ehrenberg (Bacillariophyta) of the Great Smoky Mountains National Park, USA. Bibliotheca Diatomologica 56: 1-133.

Gabito, L., Bonilla, S. \& Antoniales, D. 2013. Paleolimnological reconstruction of change in a subtropical lake: a comparison of the subfossil record to limnological data. Limnetica 32: 175-188.

Gasse, F. 1987. Diatoms for reconstructing palaeoenvironments and paleohydrology in tropical semi-arid zones. Hydrobiologia 154: 127-163.

Haworth, E. 1976. Two Late-Glacial (Late Devensian) Diatom assemblage profiles from northern Scotland. New Phytologist 77: 227-256.

Hustedt, F. 1966. Die Kieselalgen Deutschlands, Österreichs und der Schweiz. 3. In: L. Rabenhorst (ed.). Kryptogamen - Flora von Deutschland, Österreich und der Schweiz, Akademische Verlagsgesellschaft, Leipzig, pp. 816. 
Kiss, K.T., Klee, R., Ector, L. \& Acs, E. 2012. Centric diatoms of large rivers and tributaries in Hungary: morphology and biogeographic distribution. Acta Botanica Croatica 71: 311-362.

Komulaynen, S. 2009. Diatoms of periphyton assemblages in small rivers in Northwestern Russia. Studi trentini di scienze naturali 84: 153-160.

Lange-Bertalot, H., Bak, M. \& Witkowski, A. 2011. Eunotia and some related genera. In: H. Lange-Bertalot (ed.). Diatoms of Europe v. 6. Königstein, Koeltz Scientific Book, pp. 747.

Leli, I.T., Stevaux, J.C. \& Assine M.L. 2017. Genesis and sedimentary record of blind channel and islands of the an branching river: an evolution model. Geomorphology 302: 35-45.

Lobo, E.A., Callegaro, V.L.M, Hermany, G., Bes. D., Wetzel, C.A. \& Oliveira, M.A. 2004. Use of epilithic diatoms as bioindicators from lotic systems in southern Brazil, with special emphasis on eutrophication. Acta Limnologica Brasilica 16: 25-40.

Lowe, R.L., Furey, P.C., Ress, J.A. \& Johansen, J.R. 2007. Diatom biodiversity and distribution on wetwalls in Great Smoky Mountains National Park. Southeastern Naturalist, 6 (Special Issue 1), 135-152.

Lowe, R.L., Kociolek, J.P., Johansen, J.R., Van de Vijver, B., Lange-Bertalot, H. \& Kopalová, K. 2014. Humidophila gen. nov., a new genus for a clade of diatoms (Bacillariophyta) formerly within the genus Diadesmis: species from Hawai'i, including one new species. Diatom Research 29: 351-360.

Mackereth, F.Y.H., Heron, J.G. \& Talling, J. 1978. Water analysis: some revised methods for limnologist. Freshwater Biological Association 36: 1-120.

Magurran, A.E. 1988. Ecological diversity and its measurement. New Jersey: Princeton, University Press, pp. 179.

Marquardt, G.C. \& Bicudo, C.E.M. 2014. Criptógamos do Parque Estadual das Fontes do Ipiranga, São Paulo, SP. Algas 36: Bacillariophyceae (Cymbellales). Hoehnea 41: 209-246.

Metzeltin, D. \& Lange-Bertalot., H. 1998. Tropical Diatoms of South America. Iconogr. Diatomol. (H. Lange-Bertalot, ed.). v. 5, Koeltz Scientifc Books, Stuttgart, pp. 695.

Montoya-Moreno, Y. \& Aguirre-Ramírez, N. 2013. Knowledge to Ecological Preferences in a Tropical Epiphytic Alga to Use with Eutrophication Indicators. Journal of Environmental Protection 4: 27-35.

Moreira-Filho, H., Valente-Moreira, I.M. \& Cecy, I.I.T. 1973. Diatomáceas na barragem de captação d'água (SANEPAR) do rio Iguaçu, em Curitiba, Estado do Paraná. Acta Biológica Paranaense 2: 133-145.
Moreira-Filho, H. \& Valente-Moreira I.M. 1981. Avaliação taxonômica e ecológica das diatomáceas (Bacillariophyceae) epífitas em algas pluricelulares obtidas nos litorais dos Estados do Paraná, Santa Catarina e São Paulo. Boletim Museu Botânico Municipal 47: 1-17.

Moresco, C., Tremarin, P.I., Ludwig, T.A.V. \& Rodrigues, L. 2011. Diatomáceas perifíticas abundantes em três córregos com diferentes ações antrópicas em Maringá, PR, Brasil. Brazilian Journal of Botany 34: 359-373.

Moresco, C. \& Rodrigues, L. 2014. Periphytic diatom as bioindicators in urban and rural streams. Acta Scientiarum. Biological Sciences 36: 67-78.

Moro, R.S. \& Fürstenberger, C.B. 1997. Catálogo dos principais parâmetros ecológicos de diatomáceas nãomarinhas. Ed. UEPG, Ponta Grossa, pp. 282.

Ortiz-Lerín, R. \& Cambra, J. 2007. Distribution and taxonomic notes of Eunotia Ehrenberg 1837 (Bacillariophyceae) in rivers and streams of Northern Spain. Limnetica 26: 415-434.

Patrick, R. \& Reimer, C.W. 1966. The diatoms of the United States, exclusive of Alaska and Hawaii. Philadelphia, Academy of Natural Sciences 1: 1-688.

Ponader, K.C. \& Potapova, M.G. 2007. Diatoms from the genus Achnanthidium in flowing waters of the Appalachian Mountains (North America): ecology, distribution and taxonomic notes. Limnologica 37: 227-241.

Potapova, M. \& Charles, D.F. 2007. Diatom metrics for monitoring eutrophication in rivers of the United States. Ecological Indicators 7: 48-70.

Potapova, M.A. \& Hamilton, P.B. 2007. Morphological and ecological variation within the Achnanthidium minutissimum (Bacillariophyceae) species complex. Journal of Phycology 43: 561-575.

Ribeiro, F.C.P., Senna, C.S.F. \& Torgan, L.C. 2008. Diatomáceas em sedimentos superficiais na planície de Mareá da praia de Itupema, Estado do Pará, Amazônia. Rodriguésia 59: 309-324.

Ribeiro, F.C.P, Senna, C.S.F. \& Torgan, L.C. 2010. The use of diatoms for Paleohydrological and Paleoenvironmental reconstructions of Itupanema beach, Pará state, Amazon region, during the last millennium. Revista Brasileira de Paleontologia 13: 21-32.

Round, F.E., Crawford, R.M. \& Mann, D.G. 1990. The Diatoms Biology and Morphology of the Genera. London, Cambridge University Press, pp. 747.

Rühland, K.M., Paterson, A.M. \& Smol, J.P. 2015. Diatom assemblage responses to warming: reviewing the evidence. Journal of Paleolimnology 54: 1-35.

Ruwer, D.T. \& Rodrigues, L. 2018. Abundance of Diadesmis confervacea Kützing and Eunotia camelus Ehrenberg indicates the historical water level variation in a marsh. Brazilian Journal of Botany 41: 241-246. 
Santos, E.M., Tremarin, P.I. \& Ludwig, T.A.V. 2011. Periphytic diatoms on Potamogeton polygonus Cham. \& Schltdl.: first records from Paraná State. Biota Neotropica 11: 303-315.

Saulnier-Talbot, E. 2016. Paleolimnology as a Tool to Achieve Environmental Sustainability in the Anthropocene: An Overview. Geosciences 6: 1-11.

Sierra-Arango, O.R., Souza, P.A. \&Velázquez, R.C.A. 2014. Taphonomic signatures and paleoecological implications of Holocene diatom assemblages in the Llano Grande Basin, from the Frontino Páramo, northwestern Andes Cordillera, Colombia. Revista Brasileira de Paleontologia 17: 123-140.

Silva, A.M., Ludwig, T.A.V., Tremarin, P.I. \& Vercellino, I.S. 2010. Diatomáceas perifíticas em um sistema eutrófico brasileiro (Reservatório do Iraí, estado do Paraná). Acta Botanica Brasilica 24: 997-1016.

Silva, P.D.A. \& Bicudo, D.C. 2014. Diatomáceas planctônicas e desedimentos superficiais em represas de abastecimento da Região Metropolitana de São Paulo, Sudeste do Brasil. Hoehnea 41: 187-207.

Simonsen, R. 1974. The diatom plankton of the Indian Ocean expedition of R/V "Meteor". Meteor-forscheingsergeb Reihe D-Biologie 19: 1-66.

Smol, J.P. 1992. Paleolimnology: an important tool for effective ecosystem management. Journal of Aquatic Ecosystem Health 1: 49-58.

Smucker, N.J. \& Vis, M.L. 2010. Using diatoms to assess human impacts on streams benefits from multiplehabitat sampling. Hydrobiologia 654: 93-109.

Stendera, S., Adrian, R., Bonada, N., Cañedo-Argüelles, M., Hungueny, B., Januschke, K., Pletterbauer, F. \& Hering, D. 2012. Drivers and stressors of freshwater biodiversity patterns across different ecosystems and scales: a review. Hydrobiologia 696: 1-28.

Stevaux, J.C. 1994. The Upper Paraná River (Brazil): geomorphology, sedimentology and paleoclimatology. Quaternary International 21: 143-161.

Stevenson, R.J. \& Pan Y. 1999. Assessing Ecological Conditions In Rivers And Streams With Diatoms. In: E.F. Stoemer \& J.P. Smol (eds.). The diatoms: applications to the environmental and earth sciences. Cambridge, UK, Cambridge University Press, pp. 11-40.

Straube, A., Tremarin, P.I. \& Ludwig, T.A.V. 2017. Species of Luticola D.G. Mann (Bacillariophyceae) in the Atlantic Forest rivers from southern Brazil. Diatom Research 32: 417-437.

Taylor, J.C., Archibald, C.G.M. \& Harding, W.R. 2007. An Illustrated Guide to Some Common Diatom Species from SouthAfrica. Water Research Commission Report, TT282/07.

Thomaz, S.M., Roberto, M.C. \& Bini, L.M. 1997. Caracterização limnológica dos ambientes aquáticos e influência dos níveis fluviométricos. In: A.E.A.M. Vazzoler, A.A. Agostinho \& N.S. Hahn (eds.). A planície de inundação do Alto Rio Paraná: aspectos físicos, químicos, biológicos e socioeconômicos. Eduem, Maringá, pp.73-102.
Tomas, X. \& Sabater, S. 1985. The diatom associations in the Llobregat river and their relations to water quality. Verhandlungen des Internationalen Verein Limnologie, 22: 2348-2352.

Torgan, L.C. \& Santos, C.B. 2008. Diadesmis confervacea (Diadesmiaceae-Bacillariophyta): morfologia externa, distribuição e aspectos ecológicos. Iheringia - Série Botânica 63: 171-176.

Tremarin, P.I., Freire, E.G., Bertolli, L.M. \& Ludwig, T.A.V. 2009. Catálogo das diatomáceas (Ochrophyta Diatomeae) continentais do Estado do Paraná. Iheringia - Série Botânica 64: 79-107.

Tremarin, P.I., Straube, A. \& Ludwig, T.A.V. 2015. Nupela (Bacillariophyceae) in littoral rivers from south Brazil, and description of six new species of the genus. Fottea 15: 75-93.

Trobajo, R., Clavero, E., Chepurnov, V.A., Sabbe, K., Mann, D.G., Ishihara, S. \& Cox, E.J. 2009. Morphological, genetic and mating diversity within the widespread bioindicator Nitzschia palea (Bacillariophyceae). Phycologia 48: 443-459.

Valente-Moreira, I.M. 1975. Contribuição ao estudo das Bacillariophyceae (diatomáceas) em diatomitos brasileiros. Acta Biológica Paranaense 4: 135-198.

Van Dam, H., Mertens, A. \& Sinkeldam, J. 1994. A coded checklist and ecological indicator values of freshwater diatoms from the Netherlands. Aquatic Ecology 28: 117-133.

Van De Vijver, B., Ledeganck, P. \& Beyens, L. 2002. Three new species of Diadesmis from soils of Isle de la Possession (Crozet Archipelago, Subantarctic). Cryptogamie Algologie 23: 333-341.

Vélez, M.I., Berrío, J.C., Hooghiemstra, H., Metcalfe, S. \& Marchant, R. 2005. Palaeoenvironmental changes during the last ca. 8590 calibrated yr (7800-radiocarbon yr) in the dry forest ecosystem of the Patía Valley, Southern Colombian Andes: a multiproxy approach. Palaeogeography, Palaeoclimatology, Palaeoecology, 216: 279-302.

Vijayan, D. \& Ray, J.G. 2016. Ecology and Diversity of Diatoms in Kuttanadu Paddy Fields in Relation to Soil Regions, Seasons and Paddy-Growth-Stages. Journal of Plant Studies 5: 1-21.

Vyverman, W. 1991. Diatoms from Papua New Guinea. Bibliotheca Diatomologica 22: 1-223.

Wetzel, R.G. \& Likens, G.E. 1981. Limnological analyses. 2 edição. New York: Sringer-Verlag, pp. 429.

Wetzel, C.E. \& Ector, L. 2014. Taxonomy, distribution and autecology of Planothidium bagualensis sp. nov. (Bacillariophyta) a common monoraphid species from southern Brazilian rivers. Phytotaxa 156: 201-210.

Zalat, A. \& Vildary, S.S. 2007. Environmental change in Northern Egyptian Delta lakes during the late Holocene, based on diatom analysis. Journal of Paleolimnology 37: 273-299. 